\title{
Inequality and the Instability of Polity and Policy ${ }^{*}$
}

\author{
Pushan Dutt ${ }^{\dagger}$ \\ INSEAD
}

\author{
Devashish Mitra $^{\ddagger}$ \\ Syracuse University, NBER \& IZA
}

September, 2007

\begin{abstract}
We create alternative measures of political instability, which capture only movements from dictatorship to democracy and vice versa and, unlike older, well known measures does not capture government changes that preserve the democratic or dictatorial structure of the country. We show that inequality is positively correlated with our measures of political instability as well as with a well-known measure (used by Alesina and Perotti), but the impact of inequality on the latter is only through components of political instability captured by our measures. We show that our measures of political instability have significant policy implications - it increases both fiscal and trade polity volatility.
\end{abstract}

Keywords: Political instability, Policy Volatility, Inequality

JEL Classification Codes: E62, F13, F43, O40, O47, 057, P16

Short form of title for attention of printer: Inequality and Instability

\footnotetext{
* We are indebted to two anonymous referees and the editor, Andrew Scott for very valuable comments on earlier versions of this paper. We also would like to thank Ilian Mihov for very useful discussions and suggestions.

† 1 Ayer Rajah Avenue, INSEAD, Singapore 138676, Email: Pushan.Dutt@insead.edu, Ph: (65) 67995498

‡ Department of Economics, The Maxwell School of Citizenship \& Public Affairs, Syracuse University, Eggers Hall, Syracuse, NY 13244, Email: dmitra@maxwell.syr.edu, Ph: (315) 443-6143
} 
In the analysis of the significant and persistent cross-country differences in growth rates and economic development, institutions have been accorded a special role. In this paper, we focus on one important component of institutional quality - political instability. The negative relationship between political instability and economic growth is widely accepted as a stylised fact following the work of Alesina and Perotti (1996) who find that political instability reduces investment, which is a "primary engine of growth". Similarly, Alesina, Ozler, Roubini and Swagel (1996) find a negative effect of political instability on economic growth. There is, however, a notable lack of consensus in the literature on what the political instability measure captures and how it should be measured. Barro (1991) simply used the number of assassinations, and the occurrence of violent revolutions and military coups as proxies for political instability. Alesina and Perotti (1996) extend Barro's approach and use principal component analysis to construct a weighted average of the following variables that capture political unrest: mass violence, political assassinations, coups (both successful and unsuccessful) and a measure of dictatorships. Alesina, Ozler, Roubini and Swagel (1996) on the other hand, use the probability of a coup as an indicator of political instability.

Our analysis of political instability attempts to unbundle the various components of political instability and examine one particular component of political instability - movements between democratic and dictatorial regimes. We believe that traditional political instability measures, that capture things in addition to such transitions, are too broad in scope and may be subject to measurement error. We draw upon recent theoretical work by Acemoglu and Robinson (2001a and b, 2000) to construct our measure of political instability. Acemoglu and Robinson argue that unequal societies move in and out of democracy, i.e., fluctuate between being democratic and dictatorial. In a democracy with a high degree of inequality, the government has to meet the huge demands of the majority for redistribution from the rich to the poor. This results in a large net benefit for the elite to stage a coup and capture power to put in place a regime that does not allow such redistribution. The flipside of this is exactly the high net benefit for the poor of starting a revolution to snatch away power from the rich (elite) under a dictatorship. When inequality is high, redistributive policies by a dictator are not enough to prevent such a revolution. Democratisation (or extension of the franchise) will be the only answer in this 
situation. In the spirit of this analysis of political transitions, we create a new measure of political instability which captures movements from dictatorship to democracy and vice versa but does not capture government changes that preserve the democratic or dictatorial structure of the country. ${ }^{1}$ Our empirical analysis shows that while inequality is positively correlated with our measures of political instability as well as that of Alesina and Perotti, the impact of inequality on the latter is only through components of political instability as captured by our measure.

Next, we analyse the economic consequences of political instability. We argue that all kinds of redistributive policies are likely to be more volatile in politically unstable societies. And, indeed we find that policy volatility is increasing in fluctuations in the degree of democracy. More importantly, we find that the broader Alesina-Perotti measure of political instability affects policy volatility only through the components captured by our measures.

While institutions are important for economic development, a question that arises is whether policies, policy volatility and macroeconomic (in)stability have a role to play as well. In a recent paper, while Acemoglu, Johnson, Robinson, and Thaicharoen (2003) study the impact of macroeconomic policies on output volatility, they do not account for the role of volatility of these policies. We find evidence of a channel where political instability engenders policy volatility, which in turn, gets reflected in greater output volatility and lower investment. We think this finding is important since output volatility is harmful for economic growth, as has been demonstrated by Ramey and Ramey (1995), by Aizenman and Marion (1993 and 1996) for developing countries, and by Fatas and Mihov (2003). ${ }^{2}$

Our paper makes three contributions: First, we show that inequality is the key explanatory variable that accounts for fluctuations in countries' degree of democracy. Second, we show that it is this fluctuation in the degree of democracy that accounts for volatility of a broad set of policies. Finally, we propose an alternative link between political instability and economic growth and development - one that operates through policy and output volatility.

\footnotetext{
${ }^{1}$ We use the term political instability rather than political transition since our measure also captures incremental movements towards and away from democratisation.

2 The reasons that have been provided for these linkages range from delay in irreversible investment under uncertainty, to the trade-off between productive activity and unproductive activities such as rent seeking, and social and political unrest.
} 


\section{Theory}

In this section, we outline briefly the theoretical set up of Acemoglu and Robinson (2001a), and the model's main implications we will be testing empirically. Consider an economy with two groups of agents, namely the poor and the rich (the elite). We allow the possibility of the political environment being democratic or nondemocratic. In the democratic state, the tax rate is the most preferred tax rate of the median voter, who is poor (as the majority are poor). In the alternative, non-democratic regime the tax rate set is the one that maximises the utility of a representative rich agent. So when the political system is nondemocratic to begin with, an attempt at a revolution by the poor results in a decision by the elite on whether or not to democratise. Similarly, starting from a democracy, the elite will decide whether or not to stage a coup and capture power that will result in a dictatorship.

We assume that a proportion $\lambda$ of agents are identical "poor" individuals and the remaining $1-\lambda$ are identical "rich" individuals (the "elite"). We normalise the measure of the continuum of all agents to unity and assume that $\lambda>1 / 2$, i.e., the majority are poor. There is only one consumption good denoted by $y$ which is produced using asset $h$. This productive asset is distributed unequally in the economy. A poor agent has an exogenously given amount $h^{p}$ of the asset while a rich agent has $h^{r}$. The superscripts $p$ and $r$ throughout represent variables related to poor and rich respectively. Let $\theta<\lambda$ be the overall proportion of the economy's total stock of the productive asset owned by the poor and this parameter therefore is an inverse measure of inequality in the economy. Thus, we have $h^{r}=(1-\theta) h /(1-\lambda)$ and $h^{p}=\theta h / \lambda$ which represent the asset ownership of a rich and poor individual respectively. We can write the output or the pre-tax income of an agent as $y_{t}^{i}=A_{t} h^{i}$ for $i=p, r$ where the aggregate productivity $A_{t}$ can take a low value $A^{l}=a<1$ or a high value $A^{h}=1$ with probabilities $s$ and $1-s$ respectively. ${ }^{3}$

We assume identical preferences of all agents given by $E_{t} \sum_{j=0}^{\infty} \beta^{t+j} C_{t+j}^{i}$ for $i=p, r$ where $C_{t}^{i}$ is consumption of agent $i$ at time $t, \beta$ is the discount factor and $E_{t}$ is the expectations operator conditional on information available at time $t$. Assuming income taxes to be linear at rate $\tau_{t}$ at time $t$ and the lump sum transfer to be uniform of magnitude $T_{t}$, post-tax income of an individual

\footnotetext{
${ }^{3}$ Recessions are assumed not to be very common and so $s<1 / 2$. Business cycles have a role to play in this model in that they affect the opportunity costs of staging coups or attempting revolutions.
} 
$i=p, r$ can be written as $\widehat{y_{t}^{i}}=\left(1-\tau_{t}\right) A_{t} h^{i}+T_{t}$. We assume a deadweight cost of raising taxes given by $c\left(\tau_{t}\right) A_{t} h$ with $c(0)=0, c^{\prime}(0)=0, c^{\prime}(\tau)>0$ for all $\tau>0, c^{\prime}(1)=\infty$ and $c^{\prime} \geqq 0$. The government budget constraint can therefore be written as $T_{t}=\tau_{t} A_{t}\left[\lambda h^{p}+(1-\lambda) h^{r}\right]-c\left(\tau_{t}\right) A_{t} h=$ $\left(\tau_{t}-c\left(\tau_{t}\right)\right) A_{t} h$

The society starts in a nondemocratic regime (in period 0) where the poor have no say in the determination of the tax rate but can attempt a revolution in any subsequent period. The revolution succeeds only if a minimum threshold fraction of the poor take part. While a certain fraction $1-\mu>0$ of the income of the economy gets destroyed during the period of the revolution, the poor are able to obtain an additional fraction $\pi-\theta$ of the asset stock of the economy resulting in a return of $\mu \pi A_{t} h / \lambda$ in that period and $\pi A_{t} h / \lambda$ per period thereafter. A revolution is assumed to generate private benefits for a poor agent and therefore, there is no collective action problem. While a high $\mu$ implies that a revolution is not very costly, a high $\pi$ implies high returns from it for the poor. It is also assumed that the rich lose everything after a revolution and therefore, they might prevent it by voluntarily extending the franchise in which case the country transitions to a democracy and the tax rate is set thereafter through majority voting, i.e., by the median voter. Once in a democratic regime, the elite have no special voting power but can attempt a coup which succeeds if there is a minimum threshold participation by the rich. A coup brings back the status quo but in the process destroys a fraction $1-\phi$ of the economy's total income for that period.

Since there are no collective action problems, the game is solved as one between two agents, namely the elite and the poor, and the Markov Perfect Equilibria of the game are characterised by strategies that are a function only of the current state and prior actions within the same period. Under the set up described above, and imposing some reasonable restrictions, Acemoglu and Robinson are able to prove the following proposition:

Proposition 1 There exists a threshold level of $\mu$ given by $\bar{\mu}$, and two threshold levels of $\phi$ given by $\widehat{\phi}$ and $\bar{\phi}$ such that (1) if $\mu<\bar{\mu}$, the society remains undemocratic; (2) if $\mu>\bar{\mu}$ and $\phi<\widehat{\phi}$, the society democratises the first time the state is one where there is recession with the elite in power, and then remains a fully consolidated democracy; (3) if $\mu>\bar{\mu}$ and $\widehat{\phi}<\phi<\bar{\phi}$, 
the society democratises the first time the state is one where there is recession with the elite in power, and then remains a semi-consolidated democracy; and (4) if $\mu>\bar{\mu}$ and $\phi>\bar{\phi}$, the society is an unconsolidated democracy and continuously switches regimes. Importantly, $\partial \bar{\mu}$ $/ \partial \theta>0, \partial \bar{\phi} / \partial \theta>0$, and $\partial \widehat{\phi} / \partial \theta>0$.

In a consolidated democracy, the threat of a coup has no role to play, while in a semiconsolidated democracy, the threat of a coup forces the tax rate to be below the median voter's most preferred level in an otherwise democratic regime. In the first case in proposition $1, \mu$ is very low and is below the threshold level $\bar{\mu}$ which makes revolution very destructive and costly for everybody including the poor themselves, which in turn makes it unattractive for the poor and ensures that the society that starts out being undemocratic continues to be so forever. In the second case $\mu$ is higher than the threshold level $\bar{\mu}$ and so the cost of revolution is low to everyone, which makes the incentive for the poor to start a revolution high. The opportunity cost of initiating a revolution is particularly low during a recession. Under such conditions, the rich are forced to extend the franchise. Also $\phi<\widehat{\phi}$, which, once we are in a democratic regime, makes the cost of staging a coup quite high. In the third case, the cost of a revolution is not high but the cost of a coup, once the society is democratised, is in the intermediate range making the possibility and threat of a coup quite real and imminent. Thus we move to a democracy where the tax rate is below the median voter's optimum to prevent a coup. This is what Acemoglu and Robinson call a "semi-consolidated democracy". In the fourth case, $\mu>\bar{\mu}$ which means the cost of a revolution is low but at the same time $\phi>\bar{\phi}$ means that the cost of a coup is also low. Neither the coup nor the revolution is very destructive. Thus, in this case we get continuous switches in regimes.

Finally, $\partial \bar{\mu} / \partial \theta>0, \partial \bar{\phi} / \partial \theta>0$, and $\partial \widehat{\phi} / \partial \theta>0$. In other words, an increase in inequality brought about by an increase in $\theta$ reduces $\bar{\mu}, \widehat{\phi}$ and $\bar{\phi}$, which makes the minimum destruction from a coup or revolution to prevent them from happening higher. Thus at higher levels of inequality, both revolutions and coups become more attractive. The reason for this is that higher inequality leads to a higher tax rate or redistribution demanded by the median voter, which increases the difference between the median voter's most preferred tax rate and the elite's most preferred tax rate. Thus, the parameter space in which we get swings in political 
regimes increases. An obvious implication of this is that we continuously get fluctuations in tax rates and the likelihood of such fluctuations increases with an increase in inequality. In our empirical work, we will extend this result to fluctuations in both fiscal and trade policies, as both are used for redistributive purposes. We also will explore how this kind of policy volatility, by creating an uncertain economic climate, will deter investment. As shown in the literature sluggish investment negatively affects growth. Thus we are interested in the following chain of links: ${ }^{4}$

Income Inequality $\rightarrow$ Polity Instability (entry into and exit from democracy)

$\rightarrow$ High Trade and Government Spending Volatility $\rightarrow$ Output Volatility \& Low Investment $\rightarrow$ Weak Growth

\section{Measuring Political Instability}

Political instability has been conceptualised very broadly with little agreement on which components of political instability are the most critical. Barro (1991) uses the number of assassinations, and the occurrence of violent revolutions and military coups as proxies for political instability. Alesina and Perotti (1996) extend this approach and use principal component analysis to construct a weighted average of the following variables that capture political unrest: mass violence, political assassinations, coups (both successful and unsuccessful) and a measure of dictatorship. Others also focus on the harsher aspects of sociopolitical changes and differ from each other only in terms of the list of variables used in the principal component analysis. (See Hibbs, 1973, Veneiris and Gupta, 1986, and Campos and Nugent, 2002, 2003). Here political instability is a bundle of various factors - however, the discrete components may have varying underlying causes and more importantly, different consequences for economic policies and outcomes. ${ }^{5}$ Second, not all coups and revolutions are equal - some lead to real changes in the political system and how preferences of the population are aggregated (in terms of policy outcomes). Others leave

\footnotetext{
${ }^{4}$ Our focus is not so much on the growth results, but mainly on the link from inequality to political instability and from political instability to policy volatility.

${ }^{5}$ To the best of our knowledge Campos and Nugent (2002) is the only other paper that tries to distinguish between moderate and severe sociopolitical instability. They do not find strong evidence for a negative relationship between either of their measures and economic growth.
} 
the underlying political system unaffected. Examples of the latter would include failed coups (Philippines in 2006), failed revolutions (Hungary in 1956), as well as successful coups in a dictatorship (Togo in 2005) which simply change the identity of the person or elite in power with little consequence for the rest of the country's population. Third, this approach fails to account for subtle and incremental changes in political rights and political competition. Incremental restrictions (or easing of such restrictions) on political rights will not be captured by these measures. For example, we have witnessed a steady erosion of democratic rights in Kazakhstan since 1991. Finally, many of these measures define political instability primarily as a move towards dictatorial regimes - instability generated by moves from dictatorships to democracies is either ignored or underemphasised.

A second way to measure political instability would be to count the number of times a country experienced significant changes in its political organisation. One could build on the approaches used by Papaioannou and Siourounis (2004), Giavazzi and Tabellini, (2004) and Persson (2005) who identify a significant change in a country's political system if the 21 point Polity measure (ranging from -10 to +10 , with smaller values indicating a lower level of political freedom) suddenly changes from a negative to a positive value (or vice versa). While such a direct approach has its merits in that it is easily interpretable, the choice of 0 as the crucial threshold between democracy and dictatorship is somewhat ad-hoc. Moreover, a jump in the Polity measure from -1 to 1 (Honduras in 1979) would be treated equivalent to a jump from -1 to 9 (Thailand in 1991). Compared to the former, the latter is a significant move towards democracy. Finer classifications with multiple thresholds would mitigate this problem but even then we have little to guide us in terms of the number of thresholds to use. Finally, this approach would also ignore incremental changes in a country's polity.

For all these reasons, traditional measures of political instability are likely to be plagued by measurement errors insofar that it includes various factors which may not influence the political system (failed coups or riots for example,) and by failing to capture incremental changes in the country's Polity. To circumvent the shortcomings of the traditional measures, we employ a novel methodology to construct a new measure of political instability. We unbundle the various components of political instability and focus on one particular component - movements between 
democratic and dictatorial regimes.

We use annual data from Polity IV (Marshall, Jaggers and Gurr, 2000) to estimate the following dynamic panel regression:

$$
\text { POLITY } Y_{i t}=\alpha_{i}+\beta_{i}^{1} P O L I T Y_{i t-1}+\beta_{i}^{2} P O L I T Y_{i t-2}+\ldots \beta_{i}^{k} P O L I T Y_{i t-k}+\gamma_{i} \mathbf{W}_{i t}+\epsilon_{i t}
$$

where $i=1, . . N ; t=1, \ldots, T .{ }^{6}$ We included lagged values of POLITY to capture inertia in the democratic process while the vector of explanatory variables in $\mathbf{W}$ employs the conditioning set used by Robert Barro (1999). It includes per capita GDP, primary schooling attainment, the gap between male and female primary schooling, urbanisation rate, population and an oil dummy. We also add interstate and extra-state wars (see Data Appendix) to Barro's conditioning set. Our objective in the choice of explanatory variables is to capture shocks to the political system that are unrelated to the degree of development, to human capital attainment, to external wars, and to control for the inertia inherent in changing the political system. We interpret the volatility of the residual $\epsilon_{i t}$ (the unexplained component) defined as $\sqrt{\operatorname{var}_{i}\left(\epsilon_{i t}\right)}$ as a quantitative measure of political instability. ${ }^{7}$ Our measure captures fluctuations in the degree of democracy and encapsulates movements towards democracy as well as towards dictatorship. In this it is related to that Tornell's (1998) measure of political crises (a 3 point shift in the Polity score). However, Tornell (1998) measures only drastic political change while ours captures incremental shifts as well.

The first question we face is the number of autoregressive terms to include in (1). We examined various univariate specifications where we estimated how Polity in country $i$ at time $t$ depends on its lagged values. GMM estimates suggest that three lags of the dependent variable should be included in (1). The second is the choice of estimation techniques for (1). We experimented with five estimation techniques: a country-by-country OLS estimator, the Arellano-

\footnotetext{
${ }^{6}$ Note that we used the POLITY2 measure, which transforms the Polity "standardized authority codes" (i.e., $-66,-77$, and -88) to scaled POLITY scores so the POLITY scores may be used consistently in time-series analyses without losing crucial information by treating the "standardized authority scores" as missing values. Adding a time trend to (1) does not affect the results.

${ }^{7}$ In response to expected shocks to the country's Polity (that arise from a recession or an external war,) the leadership can adjust by relying on various measures such as jailing dissidents, cracking down on demonstrators, or even broadening the governing coalition. These movements in the Polity score may not be affected by inequality nor reflected in policy and output volatility.
} 
Bond system GMM technique, the Arellano-Bond difference GMM technique, the AndersonHsiao estimator (which is a special case of the Arellano-Bond difference estimator), and a simple fixed-effects estimator with country specific dummies. If poolability of coefficients is a concern, then the OLS specification is more general in that it allows the estimated coefficients in (1) to vary across countries while the other specifications constraint them to be the same. The inclusion of the lagged dependent variables as explanatory variables results in parameter estimates that are biased and inconsistent. Different estimation techniques deal with this source of inconsistency in different ways. For the system-GMM, difference-GMM and Anderson-Hsiao techniques, appropriately lagged levels of Polity serve as instruments for the lagged dependent variables. However, a drawback of this approach to estimation is the problem of weak instruments (see Hauk and Wacziarg, 2004 for a discussion) arising in small samples (small $N$ ): the first stage relationship between differenced independent variables and lagged level variables may be weak, biasing the GMM estimates. This may be of concern since we have data on only 98 countries for at least 20 years. ${ }^{8}$ Therefore, we also use a fixed-effects estimator with autoregressive terms. Recent studies suggest that for this estimator, the bias sharply decays if $T$ exceeds 20 or 30 periods (Bond, 2002), which is the case here. While the difference estimator is asymptotically consistent, it has low asymptotic precision and large biases in small samples, which leads to the need to complement it with the regression equation in levels. This gives the system GMM estimator, that joins in a single system the regression equation in differences and in levels, each with its specific set of instrumental variables. We also control for the joint endogeneity of per capita GDP and POLITY - a critical issue in the literature on political instability and growth - by instrumenting per-capita GDP with lagged GDP growth. ${ }^{9}$ Finally, all approaches can control for unobserved and time-invariant country-specific effects.

Table 1 presents the results for the fixed-effects, the system-GMM, the difference-GMM and the Anderson-Hsiao techniques. Table 2.1 presents our country-by-country OLS based measure of political instability, where countries are ranked in increasing order of political instability.

\footnotetext{
${ }^{8}$ Moreover, Hauk and Wacziarg (2004) find using Monte Carlo simulations that even with a sample size of $N=1000$ GMM estimates may be biased in the presence of measurement error.

${ }^{9}$ Rodrik and Wacziarg (2005) show that newly democratised countries experience a significant increase in economic growth controlling for other types of regime changes. See also Acemoglu et al (2005).
} 
As the ranking shows, what our measure captures is not whether a country has a high or low POLITY score (i.e., whether it is a democracy or a dictatorship) but that whether it is a stable democracy (e.g., US, Canada, UK) or a stable dictatorship (e.g., Syria, China), all of which have a low index of political instability. Moreover, it captures both transitions to and from dictatorial regimes and not simply adverse regime changes. Table 2.2 shows the pairwise correlations between the various measures of political instability - in all cases the correlation exceeds 0.66. We will present results based on the country-by-country OLS estimator, the fixedeffects estimator and the system-GMM estimator. These measures are henceforth termed the $P I^{O L S}$, the $P I^{F E}$ and $P I^{G M M}$ measures of political instability. ${ }^{10}$

\subsection{Comparing Measures of Political Instability}

First, we regress our OLS measure of political instability on various components that prior researchers have combined to form their measures of political instability (e.g., Alesina and Perotti, 1996). ${ }^{11}$ These include successful and unsuccessful coups, riots and political assassinations. We do not have data on popular revolutions aimed at restoring democracy. ${ }^{12}$ As the regression (standard errors in parentheses, $* / * * / * * *$ represent significance at the $10 \% / 5 \% / 1 \%$ levels in this and subsequent regressions) below shows our measure is significantly affected by successful coups but not by the other components. ${ }^{13}$

$$
\begin{aligned}
& P I^{O L S}=\underset{(0.22)}{-1.00^{* * *}}+\underset{(0.07)}{0.35^{* * *}} \text { successful coups }+\underset{(0.06)}{0.01} \text { unsuccessful coups }-\underset{(0.001)}{0.001 \text { riots }} \\
& +0.01 \text { assassinations; } \\
& (0.01) \\
& R^{2}=0.23, N=94
\end{aligned}
$$

Next we consider how our measure compares to the direct approach based on Papaioannou

\footnotetext{
10 Charts, summary statistics and additional results using the other estimators, are available at http://faculty.insead.edu/dutt/instability

11 Note that our measure of political instability enters all our regressions in natural logarithms. Results are similar if we use levels instead of logs.

12 The variable 'Revolutions' from Banks does not capture this concept. It is defined as any illegal or forced change in the top governmental elite, any attempt at such a change, or any successful or unsuccessful armed rebellion whose aim is independence from the central government. Clearly the scope of this variable is much broader than popular revolutions aimed at introducing democracy.

13 Similar results obtain if we run this regression for each decade separately.
} 
and Siourounis (2004) who count the number of times the Polity score transited from positive to negative and vice versa. ${ }^{14} 22$ countries (a majority of the OECD countries) receive a score of zero on both the direct measure and on $P I^{O L S}$. However, by the direct measure an additional 30 countries (53\% in all) receive a score of 0 - these are countries that experienced changes in the Polity score but did not cross the zero threshold. In contrast, only $22 \%$ receive a value of zero for $P I^{O L S}$. A few examples can help highlight the difference between the two measures. By the direct measure, countries like US, UK and Canada, receive a score of zero as do countries like Algeria and South Africa. South Africa had a Polity score of 4 during the Apartheid era which increased to 9 by 1994. The post-Apartheid era witnessed a revolutionary change in political participation, but this change is not picked up by the direct count measure. The same is the case for countries like India, Sri Lanka, and China, all of whom receive a zero score by the direct measure but owing to fluctuations in the Polity score that do not cross the 0 threshold receive a strictly positive score by the $P I^{O L S}$ measure. Similarly, Algeria fluctuates between extremely and moderately autocratic governments (the Polity score fluctuates between -9 and 2) which again the direct count measure would ignore. In contrast, Algeria is ranked as relatively unstable by $P I^{O L S}$. Spain and Zambia transited just once from dictatorship to democracy and would have identical ranks by the direct measure. However, while the former moved from a stable dictatorship (score of -9) to a stable democracy (score of 9), Zambia's commitment to political reform faded within 5 years of introducing multi-party elections in 1991 (despite this Zambia's Polity score remained positive). The $P I^{O L S}$ yields a more reasonable ranking. The two measures agree on countries that are extremely politically unstable such as Haiti, Pakistan, Peru and Thailand. To summarise, while both measures agree on countries that are either very politically unstable or very politically stable, the direct measure fails to capture incremental changes in the Polity score and fails to distinguish between major and minor changes in political rights.

We also attempt to pin down the exact differences between the Alesina-Perotti measure

\footnotetext{
${ }^{14}$ We also constructed a direct count measure based on the Gastil 7 point political rights measure. We counted the number of times this measure moved from 'Not Free' to 'Free or Partially Free' or vice versa over the period 1960-2000. The results are nearly identical to the one based on transitions in the Polity score between positive and negative values.
} 
of sociopolitical instability $(S P I)$, based on principal component analysis, and $P I^{O L S} \cdot{ }^{15}$ The Alesina-Perotti concept of political instability is broader than the ones we construct. While Alesina and Perotti would classify any society with frequent coups, deaths from mass violence, political assassinations and all other kinds social unrest that lead to changes in governments as politically unstable, our measure is about the fluctuations in the degree of democracy. In other words, a coup that leads to the replacement of a dictator by another equally autocratic dictator will add to political instability according to the Alesina-Perotti measure but not according to ours. On the other hand a coup that replaces a democracy with dictatorship will add to political volatility measured under both methods. ${ }^{16}$ The same is true about the movement in the reverse direction from dictatorship to democracy. To show this, we regress their measure on ours. The $R^{2}$ from this regression is 0.41 , meaning that fluctuations in and out of democratic regimes account for only $41 \%$ of the variation in the SPI measure. Two countries, perhaps best capture the difference between the $P I^{O L S}$ and $S P I$ measure - Great Britain and Italy. Both are ranked as relatively stable by our measure (tied at $1^{\text {st }}$ ) by our measure but relatively unstable by the Alesina-Perotti measure $\left(24^{\text {th }}\right.$ and $23^{\text {rd }}$ respectively). It does not seem very reasonable that Great Britain and Italy are similar to Colombia and Mexico (ranked $25^{\text {th }}$ and $26^{\text {rd }}$ respectively by $\left.S P I\right)$ in terms of political instability. The reason why the $S P I$ measure categorises Britain as relatively politically unstable is because the SPI measure includes deaths in mass political violence and Britain experienced racial riots over a period of three months in 1981. Similarly, Italy experienced political assassinations carried out by the Red Brigade in 1978 which is picked up by the SPI measure. However, both these phenomena were short-lived and had no affect on the degree of democracy (both countries get a maximum Polity score of 10 throughout the period of study), and accordingly neither of these countries are classified as unstable by our measure. In fact, neither countries experienced significant changes in either inequality (a driver of political instability) or in policies, investment and economic growth (that are hypothesised as affected by political instability). Another example where the two measures

\footnotetext{
${ }^{15}$ We choose the Alesina Perotti measure for two reasons: it was the first weighted measure of various events that impact sociopolitical stability and second it is the most widely cited.

${ }^{16}$ However, we do acknowledge that distinguishing types of political instability based on the outcome of riots, demonstration, purges etc. is far from ideal.
} 
differ substantially is the case of Togo - ranked $51^{\text {st }}$ by the $S P I$ measure but only $39^{\text {th }}$ by our measure. Etienne Eyadema has ruled the country with an iron fist since 1967. During this time, the country experienced various coup attempts all of which failed, as well as riots carried out by pro-democracy activists that were brutally suppressed. These would contribute to the SPI measure of political instability but not to our measure - the POLITY score of Togo has remained at -7 for most of the period till 1992 .

\section{Determinants of Political Instability}

We draw on Acemoglu and Robinson's (2001a) theory of political transition to analyse the relationship between inequality and our measures of political instability. As explained in the theory section, their model predicts that a highly unequal society is likely to fluctuate in and out of democracy. Muller and Seligson (1987) and Alesina and Perotti (1996) have previously documented the correlation between inequality and political instability. We measure inequality as the Gini coefficient and inversely as the percentage share of the median quintile in total income- Q3.Data on inequality are obtained from Dollar and Kraay (2000) and the World Bank.

To demonstrate the robustness of the relationship between inequality and our measure of political instability, we control for a variety of factors - natural resources, ethnolinguistic fractionalisation, and for colonial and regional effects. Many of the poorest developing countries have significant natural resources but all too often this income is misappropriated by powerful elites. This in turn fuels internal grievances that cause conflict and political instability. This pattern is widely referred to as the "natural resource curse" - natural resource wealth creates stagnation and conflict, rather than economic growth and development. We used the measure recently made available by the World Bank (1997) where share of natural capital in total capital (which comprises physical, human and natural capital) has been constructed for a single year, 1994. Next, it may be argued that a fractionalised population leads to multiple elite groups and competition amongst these groups for political power, some forms of which may reduce stability of political regimes, whether democratic or dictatorial. Therefore, we use the index of 
ethnolinguistic fractionalisation from Easterly and Levine (1997) as an additional explanatory variable. We also control for regional disparities in political instability by using a variety of regional dummies, and add a dummy variable that captures whether the country was a British Colony after 1918.

Table 3 looks at the relationship between political instability and inequality once all the controls are included, where three measures of political instability are regressed on three measures of inequality - the Gini coefficient from Dollar-Kraay, the high quality Gini from DeiningerSquire and $Q 3 .{ }^{17}$ From the three OLS estimates, we see that inequality (Dollar-Kraay measure) significantly exacerbates political instability supporting the Acemoglu and Robinson (2001a) assertion. This is true for two out of three of the instability measures. ${ }^{18}$ We also find that natural resource rich countries are also the ones that are politically unstable. There is some evidence that fractionalisation of the population matters and that countries that were formerly British colonies are more stable. All three models as a whole are significant and our variables account for more than $28-40 \%$ of the cross-country variation in political instability.

One of the issues that the literature has grappled with is the direction of causality between political instability and income inequality. Countries with stable political regimes and where democracy is consolidated will adopt more egalitarian policies which over time may have redistributive consequences. Since our inequality measure is averaged over time, this may be a concern. As a first step, we restricted our sample to only those countries for whom inequality data are available prior to 1980. For this sample and with Gini coefficients prior to 1980 we were able to replicate our results. However, our sample size declines to 59 countries following this restriction. To control for any other endogeneity biases as well as measurement error in the inequality variables, we also instrument inequality with land Gini from Li, Squire and Zou (1998) and schooling Gini from Castellóa and Rafael Doménech (2002) based on Barro and Lee’s measure of average schooling attainment. ${ }^{19}$ From the IV estimates in the last six columns of ta-

\footnotetext{
${ }^{17}$ We also used the WIDER measure of inequality from the World Bank and wage-inequality data from http://utip.gov.utexas.edu/data.html. While both measures significantly impact political instability, with the wage-inequality measure, our results are weaker in terms of model significance. Also see Lübker, Smith and Weeks (2002) for a critique of the Dollar-Kraay measure.

18 Note that $Q 3$ is an inverse measure of inequality so we would expect the sign to be opposite of the one obtained in the regression with the Gini coefficient. The OLS estimates for Deininger-Squire Gini coefficient and Q3 - not presented here - are highly significant as well.

19 Both land and schooling inequality should be related to income inequality and not directly related to polity
} 
ble 3, we can see that the coefficient on inequality increases in both magnitude and significance. Hansen-Sargan tests fail to reject the null hypothesis of overidentifying restrictions confirming the validity of our instruments. In sum, we conclude that there is a robust relationship between income inequality and political instability, and our tests indicate that the causal links are from inequality to political instability. In terms of the economic significance of income inequality for political instability, a one standard deviation reduction in inequality in say Congo (ranked $85^{\text {nd }}$ in table 2.1) results a reduction in $P I^{O L S}$ equivalent to less that of Mexico (rank $46^{\text {th }}$ ), which points to the critical role played by income inequality in affecting political instability.

\subsection{Comparing Measures of Political Instability}

We first regress the $S P I$ and $P I$ measures on inequality:

$$
\begin{aligned}
& S P I=-\underset{(6.46)}{12.13^{*}}+\underset{(0.15)}{0.27^{*}} \text { Gini; } R^{2}=0.05, N=66 \\
& P I=\underset{(0.75)}{-2.83^{* * *}}+\underset{(0.01)}{0.06^{* * *}} \text { Gini; } R^{2}=0.11, N=85
\end{aligned}
$$

where Gini is the Gini coefficient. Notice that inequality has a $p$-value of less than $0.1 \%$ for our measure and a $p$-value of $7.5 \%$ for the SPI measure. Moreover, inequality accounts for twice the amount of variation for our measure as compared to the SPI measure. ${ }^{20}$

We then perform the following two regressions:

$$
\begin{gathered}
P I=\underset{(0.74)}{2.58^{* * *}}+\underset{(0.01)}{0.08^{* * *}} S P I+\underset{(0.02)}{0.05^{* * *}} \text { Gini; } R^{2}=0.48 ; N=58 \\
S P I=\underset{(5.4)}{8.98}+\underset{(0.83)}{4.87^{* * *}} P I-\underset{(0.14)}{0.05} \text { Gini; } R^{2}=0.41 ; N=58
\end{gathered}
$$

instability (other than through its effect on income inequality). We test this assumption by using a HansenSargan test of overidentifying restrictions - if our instruments are important also in the determination of political instability directly, then the test would have rejected the orthogonality of the errors and the instruments. The $p$-value of the overidentification test is reported in the last row of table 3 . Table 3 also reports a test for excluded instruments and the partial $R^{2}$ from the first-stage regression. The first stage regressions are available from the authors on request. We also used the abundance of land suitable for growing wheat relative to that suitable for growing sugarcane as an instrument for inequality instead of education inequality (see Easterly, forthcoming). We obtain similar results with this measure as well.

${ }^{20}$ If we restrict the sample in both regressions to exactly the same set of countries, we observe nearly identical results. 
Clearly when $S P I$ is regressed on $P I$ and Gini, the Gini coefficient is not significant (and even has the wrong sign). This means that inequality affects the Alesina-Perotti measure of political instability only through our measure and not independently of it. On the other hand, there are effects of inequality on our measure that have two components, one correlated with Alesina-Perotti measure and the other uncorrelated with it. The last two regressions very clearly illustrate the tighter link of our measure of political instability (as opposed to the Alesina-Perotti one) with the Acemoglu-Robinson theory. This finding is robust to the inclusion of controls mentioned before. Thus, the channel through which inequality affects political instability appears to be the one described by Acemoglu and Robinson.

As a further robustness check, we attempted to capture the components of sociopolitical instability that does not result in changes in the Polity score. To do this we used principal component analysis to construct a weighted average of political assassinations, worker strike, purges, riots and anti-government demonstrations. We then performed a country-by-country IV regression where we regressed this variable on Polity and instrumented Polity with its lagged value. The residuals from this regression should capture the components mentioned above which is orthogonal to Polity. We calculated the standard error of this residual in order to compare it to $P I^{O L S}$. None of the measures of inequality significantly affects this measure. ${ }^{21}$

Next, in table 4 we analyse the effect of inequality on the various components of political instability and on the direct count measure of transitions. The first two columns reveal an insignificant relationship between the two count measures of political transitions (one based on Polity and the other on Gastil). This is not surprising given the coarseness of these measures. ${ }^{22}$ Next we look at the relationship between other components of political instability namely, political assassinations, riots in general, riots in democracies, unsuccessful coups, and coups in dictatorships. These need not result in a change in the political regime (the first four) and/or in the Polity score (coups in dictatorships). While it is important to recognise that political assassinations and riots may have non-economic roots such as race (as in the US), religion (as in

\footnotetext{
${ }^{21}$ The correlation between this measure and $P I^{O L S}$ is only 0.2 . Moreover, this measure does not impact either fiscal or trade policy volatility. In fact, if we regress fiscal or trade policy volatility simultaneously on $P I^{O L S}$ and this measure, then the latter has the wrong sign and is insignificant while $P I^{O L S}$ is positive and significant.

${ }^{22}$ We also constructed direct count measures by dividing the Polity and Gastil scales into three parts. The results and comparisons remain unchanged.
} 
Bangladesh), political ideology (as in France or Italy) and caste (as in India), it is plausible that income inequality also exercises an influence. However, as the columns 3-5 of table 4 show, we fail to find evidence for a significant relationship with inequality. Similarly, income inequality does not seem to positively influence the number of failed coups or coups in dictatorships.

\section{Consequences of Political Instability}

The analysis of the consequences of sociopolitical instability has been a central theme in the economic growth literature. (See Barro, 1991; Blomberg, 1996; Alesina et al, 1996.) Widely accepted as a stylised fact is that political instability adversely affects investment in an economy by increasing uncertainty and undermining the incentives for capital accumulation. First, when there is a significant risk of regime change, future economic policy becomes a lot more uncertain. Second, anticipating a regime change, policies may be abruptly adjusted to circumvent regime change. Theoretically, Acemoglu and Robinson (2001a) draw attention to this second point: in their paper, in a dictatorship (semi-consolidated democracy) the government may adopt policies closer (farther from) to the median voter in order to avert revolutions (coups). Given this aspect and given that different types of redistributive policies will emerge in equilibrium in democracies and dictatorships (or depending on the degree of democracy or dictatorship), political instability in terms of the movement in and out of democracy will lead to volatility in redistributive policies. Thus, policy volatility is likely to be positively associated with political instability. As a result, investors may postpone projects and/or opt for capital flight in more extreme cases. While this

link between policy volatility and political instability has been emphasised earlier, there have been no attempts to explore a direct link between the two. Instead a reduced-form approach has been adopted (e.g., Alesina and Perotti, 1996; Campos and Nugent, 2002) where the relationship between capital investment and political instability has been analysed. In this paper, we will try and explore the existence of such a direct link, and only subsequently introduce notions of investment and economic growth. 


\subsection{Measuring Fiscal and Trade Policy Volatility}

We will focus on two key components of governmental policy: fiscal policy and trade policy. We believe both to have profound implications for growth and distribution, and are subject to manipulation by political groups, lobbies and sundry interest groups. In measuring fiscal policy volatility, we follow Fatas and Mihov (2003) who study the effects of volatility in discretionary fiscal policy on economic growth. They define discretionary fiscal policy as changes in fiscal policy that are not in response to current macroeconomic conditions. We measure fiscal policy as government final consumption expenditure as a percentage of GDP. We estimate the following regression for 92 countries:

$$
G_{i t}=\alpha_{i}+\beta_{i} G_{i t-1}+\gamma_{i} Y_{i t}+\delta_{i} \mathbf{X}_{i t}+u_{i t}
$$

where $G$ is the logarithm of government spending (as a proportion of GDP), $Y$ is the logarithm of real GDP, and $\mathbf{X}$ is a vector of control variables that include inflation, inflation squared, and an an index of oil prices. Again we run a country-by-country OLS regression which controls for country-specific effects, instrumenting GDP with two lags of GDP growth. Following Fatas and Mihov, we calculate the volatility of discretionary fiscal policy (as measured by government spending) as $\sqrt{\operatorname{var}_{i}\left(u_{i t}\right)}$ which we will denote as $\sigma_{i}^{G} \cdot{ }^{23}$

Measuring trade policy volatility is more complicated. Few direct measures of trade policy exist that are comparable across countries and over time, and countries have recourse to a wide variety of direct and indirect trade policies (tariffs, quotas, VERs, subsidies to name a few). To measure trade policy volatility, we follow Pritchett (1996) who recommends that indirect measures of trade policy such as trade exposure $\left(\frac{X+M}{G D P}\right)$ measures be adjusted for country size, population and transport costs to provide a more accurate picture of trade protection. In addition, we use a direct measure of trade policy as well: import duties as a percentage of total imports. We adjust these measures for lagged dependence since changes in trade policies are relatively infrequent, the country's level of development and an index of oil prices. We also add

\footnotetext{
${ }^{23}$ We have experimented with various permutations in measuring policy volatility. These include: an AndersonHsiao estimator, a fixed effects estimator, and the Arellano-Bond system GMM estimators. In all cases the volatility measures are highly correlated with the country-by-country OLS based measure.
} 
a remoteness index (a weighted average of a country's trading partners' GDP where the weights are distance to the trading partners) to capture trading costs. ${ }^{24}$ For the two measures of trade policy, we run the regression ${ }^{25}$

$$
T P_{i t}=\alpha_{i}+\beta_{i} T P_{i t-1}+\gamma_{i} Y_{i t}+\delta_{i} \mathbf{X}_{i t}+v_{i t}
$$

using the country-by-country OLS regression and measure trade policy volatility as $\sqrt{v^{2} r_{i}\left(v_{i t}\right)}$ which we will denote it as $\sigma_{i}^{T P}$. The trade policy volatility measures based on $\left(\frac{X+M}{G D P}\right)$ and import duties are highly correlated with one another (rank correlation of 0.64 ). Table 5 shows our measures of policy volatility for the government spending based measure of fiscal volatility and the openness based measure of trade volatility. The countries have been ranked in terms of ascending order of fiscal policy volatility.

\subsection{The Effect of Political Instability on Policy Volatility}

Table 6 shows the relationship between political instability and fiscal policy volatility, while table 7 does the same for trade policy volatility. We report both OLS and IV regression results for three measures of political instability $\left(P I^{O L S}, P I^{F E}\right.$ and $\left.P I^{G M M}\right)$. In our IV estimates (to control for possible endogeneity or measurement error), we use as instruments the Gini coefficient, natural capital share and ethnolinguistic fractionalisation, which were shown in the previous section to significantly influence political instability. The Hansen-Sargan test of overidentifying restrictions in the last row of tables 6 and 7 confirm the validity of our instruments. ${ }^{26}$ In addition, we control for the following factors: in table 6 we include trade exposure, since open economies are more prone to external shocks, governments may have to resort to discretionary fiscal policy to smooth these shocks (see Rodrik, 1998); domestic

\footnotetext{
${ }^{24}$ We acknowledge that extracting trade policy volatility based on $\left(\frac{X+M}{G D P}\right)$ confounds policies with outcomes. However, our country-by-country OLS specification will rid us of many country-specific time invariant terms such as colonial and linguistic ties that affect trade volumes. One option is to use the trade restrictiveness index from UNCTAD. However, since this measure is available for very few years constructing a trade policy volatility measure is difficult. We leave this to future research.

${ }^{25}$ In our regressions, we use the log of $\left(\frac{X+M}{G D P}\right)$ but measure import duties in levels since many countries report zero import duties, especially in the 1990s. Trade policy volatility based on import duty is computed using the Anderson-Hsiao technique because many countries have limited data on import duty.

${ }^{26}$ We also instrumented political instability with land inequality and the agricultural endowment data from Easterly. The results remain unchanged as do OID tests.
} 
distortions, since these distortions may necessitate more frequent changes in discretionary fiscal policy; and various political and institutional determinants of discretionary fiscal policy (see Persson and Tabellini, 2000 for a summary). Domestic distortions are measured by calculating for each country the PPP value of the investment deflator in 1960 (relative to the US) and then calculating the deviation from the sample mean of this deflator. Political and institutional variables include the number of elections (both Presidential and Parliamentary) and a dummy for Presidential systems (see Fatas and Mihov, 2003). We control for regional effects by adding a set of regional dummies. ${ }^{27}$ In table 7 the additional explanatory variables include regional dummies, the same political institution characteristics, and the year the country joined the GATT/WTO. ${ }^{28}$

From table 6, we can see that political instability is significant across measures of policy volatility and political instability and when we control for endogeneity bias and/or measurement error by instrumenting political instability. A one standard deviation reduction in political instability (Polity measure) would reduce fiscal policy volatility (the government expenditure measure) in Argentina (ranked $89^{\text {th }}$ ) to that of Chile (ranked $62^{\text {nd }}$ ). In terms of our controls, there is some evidence that domestic distortions induce greater policy volatility.

In table 7 , we see that political instability is also a consistent and significant predictor of trade policy volatility - across measures of trade policy and across measures of political instability. These results are also robust to instrumenting for political instability using inequality. In terms of the magnitude of effects, a one standard deviation reduction in political instability, based on our IV estimates, would reduce trade policy volatility of Nigeria (ranked $67^{\text {th }}$ ) to that of Hong Kong ( $\operatorname{rank} 31^{s t}$ ). We also find that while Presidential systems do not exhibit significant differences in the volatility of trade policies, the number of elections seems to reduce trade volatility. We also find evidence that the later a country becomes part of the GATT/WTO

\footnotetext{
${ }^{27}$ In addition, we tried the following set of controls: constraints on the decision-making of the chief executive; majoritarian vs. proportional systems of democracy; percentage of years when left-wing governments were in power over the time period of the study; fractionalisation of opposition parties. None of these political determinants seem to play a significant role in affecting policy volatility.

${ }^{28}$ For countries who are not members of the GATT/WTO we set the year of accession to 2006. According to the WTO website, one of the ways for countries to demonstrate their commitment to trade policy stability is via membership in the WTO. Rose (2004) examines this hypothesis in a recent paper but finds very little support for it.
} 
the greater is its trade policy volatility. This surely warrants further investigation given the way trade policy volatility is constructed in this paper differs from that used by Rose (2004) who uses a coefficient of variation measure.

\subsection{Comparing Measures of Political Instability}

We again make an attempt to evaluate the relative explanatory power of the Alesina-Perotti measure and our measure of political instability. When we regress fiscal volatility on both these measures we obtain

$$
\sigma_{i}^{G}=-\underset{(0.09)}{2.42^{* * *}}+\underset{(0.07)}{0.21^{* * *}} P I^{O L S}+\underset{(0.01)}{0.015 S P I ; \quad N=57 ; R^{2}=0.44}
$$

which shows that it is political instability as captured by transitions between democratic and dictatorial political regimes that leads to fiscal policy volatility. This result is also robust to the addition of controls. When $P I$ is dropped from the above regression, SPI becomes significant, while on the other hand if $S P I$ is dropped instead, $P I$ remains significant. In fact, if we drop $S P I$ from this regression, then we observe an insignificant change in the coefficient on $P I$ - from 0.21 to 0.25 . When we perform a similar analysis with trade policy (based on trade exposure) we obtain

$$
\sigma_{i}^{T P}=-\underset{(0.07)}{2.49^{* * *}}+\underset{(0.06)}{0.22^{* * *}} P I^{O L S}+\underset{(0.01)}{0.004 S P I ; N} \quad N=57 ; R^{2}=0.38
$$

where again our measure seems to be the key driver of trade policy volatility - a result robust across measures of trade policy volatility and to the use of controls. Thus, even though the broad measure (Alesina-Perotti) affects policy volatility, it does so only through the AcemogluRobinson channel that our measure captures.

Next, in table 8 we regress fiscal and trade policy volatility on our alternative measures of political instability - the direct transition count measure, political assassinations, riots, riots in democracies, unsuccessful coups and coups in dictatorships. Only the direct transition count measure significantly impacts both types of policy volatility - the rest are insignificant and even have the wrong sign. It seems plausible that riots, assassinations, failed coups and coups in dictatorships often do not affect the Polity score and therefore do not mark a fundamental shift 
in the way the Polity arrives at policy decisions. Therefore these do not lead to a volatility in trade and fiscal policies. ${ }^{29}$ Comparing the effects of our measure of political instability with the direct transition measure we find that a one standard deviation in the former increases policy volatility by a magnitude that is more than 2.5 that for the latter.

To summarise, we find strong empirical evidence that political instability as captured by transitions between democracies and dictatorships, engenders significant policy volatility and creates an uncertain policy environment. We also find evidence that income inequality indirectly leads to policy uncertainty (which is what our IV regressions say where inequality is an instrument for political instability). It leads to fluctuations in the degree of democracy, which in turn creates policy volatility as regime turnover results in new policies. This is the mechanism that Acemoglu and Robinson (2001a) have documented in their study of the consolidation of democracy.

\section{$5 \quad$ Political Instability, Policy Volatility and Economic Outcomes}

Now that we have demonstrated a robust link between political instability and policy volatility the question that naturally arises is: what are the adverse consequences, if any, of policy volatility? Here we examine how policy volatility (and political instability) affects output volatility and second, how policy and output volatility affects investment. It is well known that investment and output stability are positively associated with economic growth. Levine and Renelt (1992) used Leamer's extreme bounds analysis to show that the share of investment in GDP is one of the few variables that is robustly correlated with economic growth. Similarly, Ramey and Ramey (1995) and Fatas and Mihov (2003), demonstrate that countries with higher output volatility experience lower economic growth. ${ }^{30}$ While we were able to replicate the growth results

\footnotetext{
${ }^{29}$ To check the plausibility of this statement, we added riots, strikes by workers and political assassinations in our first stage regression of Polity on its lagged values and the conditioning set of Barro. Only strikes are significant but they enter with a positive sign, i.e., countries that experience more strikes are in fact more likely to democratise. We ran these regressions with various specifications (fixed effects, GMM, Anderson-Hsiao) as well as separately by decade - we find no evidence that either of these negatively and significantly affect the Polity score. Acemoglu and Robinson (2001a) also argue that incumbent political regimes find it difficult to commit to policy changes.

${ }^{30}$ In the standard neoclassical growth model, policy uncertainty does not play any role in determining the long-run growth rate of per capita output and policy shocks displace the economy only temporarily from its original growth path. In contrast, models of endogenous growth suggest that policies and policy volatility can
} 
in the context of our paper, we do not present detailed results due to space constraints.

\subsection{Output Volatility}

We follow Ramey and Ramey (1995) and Fatas and Mihov (2003) and measure output volatility as the standard deviation of the annual growth rate of GDP per capita for each of the countries in our sample. We estimate the following model:

$$
\log \left(\sigma_{i}^{y}\right)=\alpha+\beta \log \left(\sigma_{i}^{G}\right)+\gamma \log \left(\sigma_{i}^{T P}\right)+\delta \mathbf{Z}_{i}+v_{i}
$$

where $\sigma_{i}^{G}$ and $\sigma_{i}^{T P}$ are defined as before. Following Acemoglu et al (2003) the vector $\mathbf{Z}$ includes the following policy variables: inflation, exchange rate overvaluation, government consumption expenditure, openness (measured as $\frac{X+M}{G D P}$ since greater openness may expose the country to more external shocks), and volatility in the country's terms of trade.

We first ran the following simple regression:

$$
\text { output volatility }=\underset{(0.05)}{1.49^{* * *}}+\underset{(0.03)}{0.13^{* * *}} P I^{O L S} ; N=80, R^{2}=0.21
$$

which indicates that political instability is positively related to output volatility. In Table 9 , we present our detailed results on how output volatility depends on policy volatility and political instability: Both our OLS and IV results show that fiscal policy volatility and trade policy volatility, when entered separately, positively affect output volatility. The volatility measures remain significant even when the controls are dropped. In our IV regressions, we control for the endogeneity of fiscal and trade policy volatility using the following instruments: political instability (Polity measure), electoral system, the number of elections, domestic distortions and date of GATT/WTO membership. For our IV regressions, the coefficient estimates show that a $1 \%$ decline in fiscal (trade) policy volatility reduces output volatility by $0.97 \%(0.74 \%)$. These results work continue to hold when we use only political instability as an instrument for policy volatility. When both policy volatility measures are included, the OLS estimates show that both significant at the $1 \%$ level. However, when entered together and instrumented, only have permanent effects on growth (see Aizenman and Marion, 1999 and King et al 1988 as examples). 
trade policy volatility is significant at $5 \%$, due to strong multicollinearity. ${ }^{31}$ Among the controls, only openness is statistically significant and enters with a positive sign. The significance and the positive sign of the political instability variable in the simple regression (shown above) of output volatility on political instability, indicates that political instability affects output volatility. However, from table 9, it is clear that this affect works only through its effect on policy volatility. ${ }^{32}$

Comparing the two measures of trade policy volatility (columns 3-6), fluctuations in trade exposure have a proportionately bigger impact, in terms of magnitude, than do fluctuations in import duties. One reason for this is that governments have access to a wide variety of trade policy instruments (quotas, export subsidies, VERs etc.) that would show up in greater volatility of the trade exposure measure. Governments who have committed to tariff levels in international agreements also implicitly protect sectors through domestic policies that act as substitutes for import protection (Bagwell and Staiger, 2006). Standard trade policy measures like import duties would fail to capture these aspects but they would be encapsulated in the trade exposure based measure.

\subsection{Investment and Growth}

Volatility, whether of policies or output, may play a role in deterring investment. When investments are irreversible, volatility of output and policies exacerbate uncertainty about the future and investors may adopt a "wait-and watch" attitude since there is an option value to waiting for information to arrive. We find that both trade and fiscal policy volatility adversely affect investment, controlling for other determinants of investment spending; these include schooling (measured by the percentage of population above 25 with primary education,) domestic distortions, openness and regional dummies. This effect is also robust to instrumenting the policy

\footnotetext{
${ }^{31}$ The $R^{2}$ obtained from regressing the predicted value (from the first stage of the 2SLS regressions) of one on that of the other is 0.97 which indicates very high collinearity.

32 When political instability is added as a regressor, it turns out to be statistically insignificant. We also substituted the measure of political instability with the Polity measure itself as a composite indicator for political and democratic institutions. Our results remain unchanged - Polity has an independent effect on output volatility and the policy volatility measures remain strongly significant. This result contrasts sharply with that of Acemoglu et al (2003) who find that political institutions and not macroeconomic policies are the main driver of output volatility. However, they focus on policies rather than on policy volatility, which we find to be a critical driver of output volatility.
} 
volatility variables with three measures of political institutions - political instability, the number of elections and a dummy for Presidential systems. The presence of political instability as an instrument for policy instability, indicates that political instability lowers investment, and that it does so by exacerbating volatility of trade and fiscal policies. Second, instrumenting output volatility with the two policy volatility variables, we find that output volatility significantly and adversely affects investment spending. Third, 3SLS estimates, where we also instrument the policy volatility measures using political instability suggest that political instability increases policy volatility which in turn, raises the volatility of output and that this acts as a significant deterrent to investment spending. Finally we regress economic growth on output volatility, investment spending, initial human capital and initial per capita GDP. The coefficient of output volatility turns out to have a negative sign and is significant, while that of investment spending is positive and significant.

\section{Robustness Across Decades}

The relationships we have identified so far are for data on different kinds of volatility or instability calculated over four decades, and therefore these relationships certainly hold in the long run. To confirm their validity in the short run, we run these regressions for each of these four decades separately. Table 10 shows that the relationship between political instability and inequality as fairly robust across decades. It holds for the 1970s, 1980s and 1990s separately for which inequality has a positive and significant impact on political instability, while the effect is statistically insignificant for the 1960s. The coefficient of political instability, when either fiscal or trade policy volatility is regressed on it, is positive and significant for each of these four decades. When we pool data across decades, the results with country-specific fixed and random

effects have the right signs for all three regressions, and are statistically significant in all cases except for the fixed effects model of political instability regressed on inequality. 


\section{Conclusion}

This paper uses a new methodology to construct measures of political instability that capture movements only from dictatorship to democracy and vice versa but do not capture government changes that preserve the democratic or dictatorial structure of the country. We show that unequal societies move in and out of democracy, i.e., fluctuate between being democratic and dictatorial. Our empirical work clearly shows that inequality is positively correlated with our measures of political instability as well as with more traditional measures (e.g., Alesina and Perotti,) but the impact of inequality on the latter is only through components of political instability as captured in our measures. Moreover, our residual based measures of political instability perform better than a direct count measure in terms of ranking countries and are more closely linked to income inequality. We also find evidence that volatility of a broad set of trade and fiscal policies is increasing in fluctuations in the degree of democracy. Further, we find that the Alesina-Perotti measure of political instability (that is broader and captures additional aspects of political instability) affects policy volatility only through the components of instability captured by our measures.

We next find that output volatility is affected by political instability but only through its effect on policy volatility. We find strong evidence of a channel that starts from inequality which then affects political instability which in turn affects policy volatility and then output volatility. Further, we find that policy volatility adversely affects investment, through its effect on output volatility. Output volatility and investment significantly impact economic growth. We therefore, are able to trace out an alternative link between political instability and economic growth - one that operates through policy and output volatility.

\section{References}

Acemoglu, D., Johnson, S. and Robinson, J. A. (2000). 'Why did the West extend the franchise? Democracy, inequality, and growth in historical perspective', Quarterly Journal of Economics, vol. 115(4), pp. 1167-99.

Acemoglu, D. and Robinson, J. A. (2001a). 'A theory of political transitions', American Economic Review, vol. 91(4), pp. 938-963. 
Acemoglu, D., Johnson, S. and Robinson, J. A. (2001b). 'The colonial origins of comparative development: An empirical investigation', American Economic Review, vol. 91(5), pp. 1369-1401.

Acemoglu, D., Johnson, S., Robinson, J. A. and Thaicharoen, Y. (2003). 'Institutional causes, macroeconomic symptoms: Volatility, crises and growth', Journal of Monetary Economics, vol. 50(1), pp. 49-123.

Acemoglu, Daron, Johnson, S., Robinson, J. A. and Yared, P. (2005). 'Income and democracy', NBER Working Paper 11205.

Aizenman, J. and Marion, N. (1993). 'Policy uncertainty, persistence and growth', Review of International Economics, vol. 1(2), pp. 145-63.

Aizenman, J. and Marion, N. (1999). 'Volatility and investment: Interpreting evidence from developing countries', Economica, vol. 66(262), pp. 157-79.

Alesina, A., Ozler, S., Roubini, N. and Swagel, P. (1996). 'Political instability and economic growth', Journal of Economic Growth, vol. 1(2), pp. 189-211.

Alesina, A. and Perotti, R. (1996). 'Income distribution, political instability, and investment', European Economic Review, vol 40(6), pp. 1203-28.

Bagwell, K. and Staiger, R.W. (2006). 'Will international rules on subsidies disrupt the world trading system?', American Economic Review, vol. 96(3) pp. 877-95.

Barro, R. (1991). 'Economic growth in a cross section of countries', Quarterly Journal of Economics vol. 106(2), pp. 407-44.

Barro, R. and Lee, J.W., (2000). 'International data on educational attainment: Updates and implications', CID Working Paper No. 42.

Blomberg, S.B. (1996). 'Growth, political instability and the defence burden', Economica, vol. $63(252)$, pp. 649-72.

Bond, S. (2002). 'Dynamic panel data models: A guide to micro data methods and practice'. Institute for Fiscal Studies, Cemmap Working Paper CWP09/02.

Campos, N.F. and Nugent, J.B. (2002). 'Who is afraid of political instability?', Journal of Development Economics, vol. 67(1), pp. 157-72.

Campos, N. F. and Nugent, J. B. (2003). 'Aggregate investment and political instability: An econometric investigation', Economica, vol. 70(3), pp. 533-49.

Castellóa, A. and Doménech, R. (2002). 'Human capital inequality and economic growth: Some new evidence', ECONOMIC JOURNAL, vol. 112(478), pp. 187-200.

Dollar, D. and Kraay, A. (2002). 'Growth is good for the poor', Journal of Economic Growth, vol. 7(3), pp. 195-225.

Easterly, W. and Levine, R. (1997). 'Africa's growth tragedy: Policies and ethnic divisions', Quarterly Journal of Economics, vol. 112(4), pp. 1203-50. 
Easterly, W. (forthcoming). 'Inequality does cause underdevelopment', Journal of Development Economics.

Fatas, A. and Mihov, I. (2003). 'The case for restricting fiscal policy discretion', Quarterly Journal of Economics, vol. 118(4), pp. 1419-47.

Giavazzi, F. and Tabellini, G. (2004), "Economic and political liberalisations', NBER Working Paper, 10657.

Hauk, W. R. Jr. and Wacziarg, R. (2004). 'A Monte Carlo study of growth regression', NBER Technical Working Paper 296.

Hibbs, D.A. (1973). Mass Political Violence: A Cross-Sectional Analysis, Wiley and Sons: New York.

King, R. G., Plosser, C. I. and Rebelo, S.T. (1988). 'Production, growth and business Cycles: I. The Basic Neoclassical Model', Journal of Monetary Economics, vol. 21(2-3), pp. 195-232.

Levine, R. and Renelt, D. (1992). 'A sensitivity analysis of cross-country growth regressions', American Economic Review, vol. 82 (4), pp. 942-963.

Li, H., Squire, L. and Zou, H. (1998). 'Explaining international and intertemporal variations in income inequality', ECONOMIC JOURNAL, vol. 108(446), pp. 26-43.

Lübker, M., Smith, G. and Weeks, J. (2002). 'Growth and the poor: a comment on Dollar and Kraay', Journal of International Development, 14(5), 555-71.

Marshall, M. G., Jaggers, K. and Gurr, T.R. (2000). 'Political regime characteristics and transitions, 1800-2002', Polity IV Project, Center for International Development and Conflict Management at the University of Maryland, College Park.

Muller, E. N., and Seligson, M. A. (1987). 'Inequality and insurgency', American Political Science Review, vol. 81(2), pp. 425-52.

Papaioannou, E. and Siourounis, G. (2004). 'Democratisation and growth', London Business School Economics Discussion Paper.

Persson, T. and Tabellini, G. (2000). Political Economics: Explaining Economic Policy. MA: MIT Press.

Persson, T. (2005). 'Forms of democracy, policy and economic development'. NBER Working Paper 11171.

Pritchett, L., (1996). 'Measuring outward orientation in LDCs: Can it be done?', Journal of Development Economics, vol. 49(2), pp. 307-35.

Ramey, G. and Ramey, V. (1995). 'Cross-country evidence on the link between volatility and growth', American Economic Review,vol. 85(5), pp. 1138-51.

Rodrik, D. (1998). 'Why do more open economies have bigger governments?', Journal of Political Economy, vol. 106(5), pp. 997-1032. 
Rodrik, D. and Wacziarg, R. (2005). 'Do democratic transitions produce bad economic outcomes?', American Economic Review Papers and Proceedings, vol. 95(2), pp. 50-55.

Rose, A. (2004). 'Does the WTO make trade more stable'? NBER Working Paper 10207.

Sachs, J. and Warner, A. (2001). 'The curse of natural resources', European Economic Review, vol. 45(4-6), pp. 827-38.

Tornell, A. (1998). 'Reform from within', NBER Working Paper 6497.

Veneiris, Y. and Gupta, D. (1986). 'Income distribution and socio-political instability as determinants of savings: A cross-sectional model', Journal of Political Economy, Vol. 94(4), pp. 873-83. 


\section{Data Series Used for the Construction of Political Instability and Policy Volatility}

\begin{tabular}{|c|c|}
\hline $\begin{array}{l}\text { Polity score } \\
(1960-2000)\end{array}$ & $\begin{array}{l}\text { Polity data adjusted for standardised scores (Polity } 2 \text { in database) from IV Project, } \\
\text { Center for International Development and Conflict Management at the University of } \\
\text { Maryland, College Park. (Marshall, Jaggers and Gurr, 2000) }\end{array}$ \\
\hline $\begin{array}{l}\text { Real GDP per capita } \\
(1960-2000)\end{array}$ & $\begin{array}{l}\text { Real GDP per capita on Purchasing Power Parity basis from Penn World Tables } \\
\text { (version 6.1). }\end{array}$ \\
\hline $\begin{array}{l}\text { Schooling } \\
(1960-2000)\end{array}$ & $\begin{array}{l}\text { Average years of primary schooling attained in population above } 25 \text {. From Barro \& } \\
\text { Lee (2000) }\end{array}$ \\
\hline $\begin{array}{l}\text { Gender gap in } \\
\text { schooling } \\
(1960-2000)\end{array}$ & $\begin{array}{l}\text { Gap between male and female primary schooling attainment. From Barro \& Lee } \\
\text { (2000) }\end{array}$ \\
\hline $\begin{array}{l}\text { Population } \\
(1960-2000)\end{array}$ & Country’s population from World Development Indicators (2002). \\
\hline Urbanisation & Percentage of population residing in urban areas from World Development \\
\hline$(1960-2000)$ & Indicators (2002). \\
\hline Oil dummy & Dummy $=1$ if country classified as oil-exporter by IMF. \\
\hline $\begin{array}{l}\text { Inter-State Wars } \\
(1960-1999)\end{array}$ & $\begin{array}{l}\text { Wars in which a nation that qualifies as a member of the interstate system engages in } \\
\text { a war with another member of the interstate system. To qualify as a state member of } \\
\text { the interstate system an entity must have a minimum population of 500,000 and } \\
\text { either membership in the League of Nations or United Nations or diplomatic } \\
\text { recognition from any two major powers. From Armed Conflict Dataset, NRIO. }\end{array}$ \\
\hline $\begin{array}{l}\text { Extra-State Wars } \\
(1960-1999)\end{array}$ & $\begin{array}{l}\text { Includes two types of wars. First, imperial war, involves an adversary that is an } \\
\text { independent political entity but does not qualify as a member of the interstate } \\
\text { system. Second, colonial war, includes international wars in which the adversary was } \\
\text { a colony, dependency or protectorate composed of ethnically different people and } \\
\text { located at some geographical distance or, at least, peripheral to the center of } \\
\text { government of the given system member. From Armed Conflict Dataset, NRIO. }\end{array}$ \\
\hline $\begin{array}{l}\text { Index of oil prices } \\
(1960-1999)\end{array}$ & $\begin{array}{l}\text { Logarithm of Petroleum spot price from International Financial Statistics, December } \\
2002 .\end{array}$ \\
\hline $\begin{array}{l}\text { Inflation } \\
(1960-1999)\end{array}$ & The difference in the logarithm of the GDP deflator from WDI, 2002. \\
\hline Growth Rate of real & The difference in the logarithm of real GDP in constant local currency units from \\
\hline $\begin{array}{l}\text { GDP } \\
(1960-1999)\end{array}$ & WDI, 2002. \\
\hline $\begin{array}{l}\text { Real government } \\
\text { consumption } \\
(1960-2000)\end{array}$ & $\begin{array}{l}\text { General government final consumption expenditure includes all government current } \\
\text { expenditures for purchases of goods and services (including compensation of } \\
\text { employees). Includes most expenditure on national defence and security, but not } \\
\text { those that are part of government capital formation. Data are from WDI, } 2002 .\end{array}$ \\
\hline $\begin{array}{l}\text { Trade exposure } \\
(1960-2000)\end{array}$ & The sum of exports and imports divided by GDP. Data from WDI, 2002. \\
\hline $\begin{array}{l}\text { Import duties } \\
(1960-1999)\end{array}$ & Import duties as a fraction of total imports. Data from WDI, 2002. \\
\hline $\begin{array}{l}\text { Remoteness index } \\
(1960-1999)\end{array}$ & $\begin{array}{l}\text { Weighted average of each country's trading partners' GDP where the weights are } \\
\text { distance to the trading partners. From Andrew Rose's website. } \\
\text { http://faculty.haas.berkeley.edu/arose/ }\end{array}$ \\
\hline
\end{tabular}

Note: For the decadal results in table 10 we used the same variables, but reran all the regressions separately by decade. 


\section{Data Series used in the Cross-Sectional Regressions (all measures are averaged over 1960-2000 unless otherwise mentioned)}

\begin{tabular}{|c|c|}
\hline Gini & $\begin{array}{l}\text { Gini coefficients from Dollar and Kraay (2002) and Deininger Squire. Data for the } \\
\text { latter available at http://www.worldbank.org/research/inequality/data.htm }\end{array}$ \\
\hline Q3 & Share of the median quintile in income. \\
\hline $\begin{array}{l}\text { Natural capital share } \\
\text { (1994) }\end{array}$ & $\begin{array}{l}\text { The sum of the stock value of agricultural land, pasture land, timber, non-timber } \\
\text { forest benefits, oil, coal, natural gas, metals, minerals and ores. From World Bank. }\end{array}$ \\
\hline Ethnolinguistic & Index of ethnolinguistic fractionalisation, 1960 . Measures probability that two \\
\hline Fractionalisation (1960) & $\begin{array}{l}\text { randomly selected people from a given country will not belong to the same ethnic } \\
\text { group. From Easterly and Levine, } 1996 \text {. }\end{array}$ \\
\hline British colony & $\begin{array}{l}\text { Dummy variable which equals one if country was a British colony. Data are from } \\
\text { Hall and Jones, } 1999 .\end{array}$ \\
\hline Land inequality & Land Gini from Li, Squire and Zou (1998) \\
\hline $\begin{array}{l}\text { Schooling inequality } \\
(1960)\end{array}$ & $\begin{array}{l}\text { Schooling Gini for the population aged } 15 \text { years and over from Castellóa and Rafael } \\
\text { Doménech (2002) }\end{array}$ \\
\hline Openness & Logarithm of the sum of imports and exports as \% of GDP from WDI, 2002. \\
\hline Domestic distortions & $\begin{array}{l}\text { Measured by calculating for each country the PPP value of the investment deflator in } \\
1960 \text { (relative to the US) and then calculating the deviation from the sample mean of } \\
\text { this deflator. }\end{array}$ \\
\hline Presidential system & $\begin{array}{l}\text { Dummy variable that takes a value of } 1 \text { for Presidential systems and } 0 \text { for } \\
\text { proportional systems. Data from the Database of Political Institutions (DPI), } 2001\end{array}$ \\
\hline Number of elections & $\begin{array}{l}\text { The average number of elections over the time period for which data are available. } \\
\text { The series is constructed as the sum of legislative and executive elections from DPI, } \\
2001\end{array}$ \\
\hline $\begin{array}{l}\text { Date of GATT/WTO } \\
\text { accession }\end{array}$ & Date country joined GATT/WTO. From Rose (2004). \\
\hline Schooling & Secondary schooling of males over 25. From Barro and Lee (2000). \\
\hline $\begin{array}{l}\text { Terms of trade } \\
\text { volatility }\end{array}$ & $\begin{array}{l}\text { Standard deviation of country's terms of trade over the period 1960-2000. Data on } \\
\text { terms of trade from International Financial Statistics, December 2002. }\end{array}$ \\
\hline $\begin{array}{l}\text { Exchange rate } \\
\text { overvaluation }\end{array}$ & Overvaluation index from Dollar (1992) \\
\hline Investment & Investment as a percentage of GDP. From Penn World Tables (version 6.1). \\
\hline $\begin{array}{l}\text { Political transitions } \\
\text { (Polity) }\end{array}$ & $\begin{array}{l}\text { Number of times Polity measure moved from positive to negative or vice versa over } \\
\text { the period } 1960-2000 \text {. }\end{array}$ \\
\hline $\begin{array}{l}\text { Political transitions } \\
\text { (Gastil) }\end{array}$ & $\begin{array}{l}\text { Number of times Gastil political rights measure moved from `Not Free' to `Free or } \\
\text { Partially Free' or vice versa over the period } 1960-2000 \text {. }\end{array}$ \\
\hline Political assassinations & $\begin{array}{l}\text { Any politically motivated murder or attempted murder of a high government official } \\
\text { or politician. From Arthur Banks. }\end{array}$ \\
\hline Riots & $\begin{array}{l}\text { Any violent demonstration or clash of more than } 100 \text { citizens involving the use of } \\
\text { physical force. From Arthur Banks }\end{array}$ \\
\hline Successful coups & $\begin{array}{l}\text { The number of extra constitutional or forced changes in the top government elite } \\
\text { and/or its effective control of the nation's power structure in a given year. From } \\
\text { Arthur Banks. Note the Banks database does not include unsuccessful coups. }\end{array}$ \\
\hline Unsuccessful coups & Number of unsuccessful coups, 1960-85, from Alesina et al, 1996. \\
\hline
\end{tabular}




\begin{tabular}{|c|c|c|c|c|}
\hline & Table 1: F & Stage Re & sults & \\
\hline & Fixed Effects & GMM system & GMM difference & Anderson-Hsiao \\
\hline & (1) & (2) & (3) & (4) \\
\hline Polity(t-1) & $0.976^{\star \star \star}$ & $0.841^{\star \star \star}$ & $0.329^{\star \star \star}$ & $1.052^{\star \star \star}$ \\
\hline & $(0.017)$ & $(0.032)$ & $(0.076)$ & $(0.282)$ \\
\hline Polity(t-2) & $-0.107^{\star \star \star}$ & $-0.09^{\star \star \star}$ & -0.019 & $-0.099 \star \star \star *$ \\
\hline & $(0.024)$ & $(0.029)$ & $(0.029)$ & $(0.031)$ \\
\hline Polity(t-3) & -0.009 & $-0.143^{\star \star \star}$ & $-0.501^{\star \star \star}$ & -0.044 \\
\hline & $(0.017)$ & $(0.033)$ & $(0.107)$ & $(0.029)$ \\
\hline years of primary schooling & 0.136 & 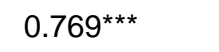 & $6.893^{\star \star \star}$ & 0.819 \\
\hline & $(0.132)$ & $(0.28)$ & (1.691) & (2.771) \\
\hline gender gap in primary schooling & $0.267^{*}$ & -1.159 & $-13.413^{\star \star \star}$ & 0.592 \\
\hline & $(0.14)$ & $(0.734)$ & $(3.255)$ & $(0.736)$ \\
\hline urbanisation rate & $0.026^{\star \star}$ & -0.002 & -0.403 & -0.079 \\
\hline & $(0.01)$ & $(0.019)$ & $(0.326)$ & $(0.211)$ \\
\hline $\log ($ population) & $0.73^{\star \star}$ & 0.284 & 5.307 & -0.273 \\
\hline & $(0.303)$ & $(0.231)$ & $(6.142)$ & $(4.256)$ \\
\hline oil dummy & & -0.818 & & \\
\hline & & $(1.643)$ & & \\
\hline $\log ($ per capita GDP) & -0.105 & 0.258 & -2.914 & 2.827 \\
\hline & $(0.134)$ & $(0.394)$ & $(3.085)$ & $(5.386)$ \\
\hline extra-state wars & $-0.739^{\star *}$ & 0.989 & 5.912 & -0.068 \\
\hline & $(0.43)$ & (2.473) & (9.899) & (1.214) \\
\hline inter-state wars & -0.197 & $-1.667^{\star *}$ & 0.043 & -0.227 \\
\hline & $(0.172)$ & $(0.714)$ & $(0.712)$ & $(0.262)$ \\
\hline constant & $-7.36^{\star \star \star}$ & -5.519 & & \\
\hline & $(2.654)$ & $(3.54)$ & & \\
\hline No. of observations & 3450 & 3450 & 3350 & 3350 \\
\hline No. of countries & 98 & 98 & 98 & 98 \\
\hline F-statistic & $1463.27^{\star \star \star}$ & $195.21^{\star \star *}$ & $14.66^{\star \star \star}$ & $5.0^{* \star *}$ \\
\hline Specification tests (p-values) & & & & \\
\hline (a) OID test & & 1 & 1 & 0.2 \\
\hline (b) Serial correlation & & & & \\
\hline First order & & 0 & 0.003 & \\
\hline Second order & & 0.46 & 0.862 & \\
\hline
\end{tabular}


Table 2.1: An Index of Political Instability (OLS Country-by-Country)

\begin{tabular}{|c|c|c|c|c|c|}
\hline Australia & 0 & Venezuela & 0.40 & Benin & 1.74 \\
\hline Austria & 0 & Yugoslavia, FR (Serbia) & 0.41 & Uganda & 1.85 \\
\hline Belgium & 0 & Colombia & 0.42 & Brazil & 1.91 \\
\hline Botswana & 0 & France & 0.46 & Korea, Rep. & 1.93 \\
\hline Canada & 0 & Rwanda & 0.50 & Gambia, The & 1.96 \\
\hline Switzerland & 0 & Togo & 0.51 & Sierra Leone & 2.06 \\
\hline Costa Rica & 0 & Bahrain & 0.57 & Iran, Islamic Rep. & 2.09 \\
\hline Germany & 0 & Cameroon & 0.70 & Dominican Republic & 2.10 \\
\hline Denmark & 0 & Honduras & 0.71 & Ecuador & 2.20 \\
\hline Finland & 0 & Spain & 0.71 & Fiji & 2.22 \\
\hline United Kingdom & 0 & Tunisia & 0.72 & Central African Rep. & 2.26 \\
\hline Ireland & 0 & Syrian Arab Republic & 0.73 & Bolivia & 2.29 \\
\hline Iceland & 0 & Mexico & 0.81 & Philippines & 2.32 \\
\hline Italy & 0 & Egypt, Arab Rep. & 0.84 & Ghana & 2.33 \\
\hline Japan & 0 & Jordan & 0.93 & Greece & 2.36 \\
\hline Netherlands & 0 & Bangladesh & 0.94 & Chile & 2.42 \\
\hline Norway & 0 & Liberia & 0.95 & Sudan & 2.51 \\
\hline New Zealand & 0 & El Salvador & 0.98 & Niger & 2.67 \\
\hline Papua New Guinea & 0 & Portugal & 1.00 & Congo, Rep. & 2.78 \\
\hline Singapore & 0 & Hungary & 1.01 & Uruguay & 2.91 \\
\hline Sweden & 0 & Congo, Dem. Rep. & 1.25 & Panama & 2.98 \\
\hline United States & 0 & Mali & 1.39 & Nepal & 3.08 \\
\hline China & 0 & Paraguay & 1.41 & Thailand & 3.10 \\
\hline Mauritius & 0.17 & Nicaragua & 1.43 & Turkey & 3.12 \\
\hline Swaziland & 0.18 & Algeria & 1.44 & Peru & 3.36 \\
\hline Jamaica & 0.19 & Malaysia & 1.45 & Malawi & 3.75 \\
\hline Israel & 0.21 & Zimbabwe & 1.49 & Lesotho & 4.16 \\
\hline Trinidad and Tobago & 0.23 & Kenya & 1.51 & Argentina & 4.57 \\
\hline South Africa & 0.34 & Senegal & 1.57 & Zambia & 4.63 \\
\hline India & 0.34 & Mozambique & 1.57 & Pakistan & 4.85 \\
\hline Cyprus & 0.36 & Poland & 1.61 & Haiti & 5.13 \\
\hline Iraq & 0.39 & Guatemala & 1.66 & Indonesia & 5.49 \\
\hline Sri Lanka & 0.39 & Kuwait & 1.73 & & \\
\hline
\end{tabular}

Table 2.2: Correlation Between Political Instability Measures

OLS Fixed Effects GMM-System GMM-Difference Anderson-Hsiao OLS 1

\begin{tabular}{|c|c|c|c|c|c|}
\hline Fixed Effects & 0.92 & 1 & & & \\
\hline GMM-System & 0.87 & 0.90 & 1 & & \\
\hline GMM-Difference & 0.66 & 0.66 & 0.69 & 1 & \\
\hline Anderson-Hsiao & 0.97 & 0.95 & 0.91 & 0.68 & 1 \\
\hline
\end{tabular}




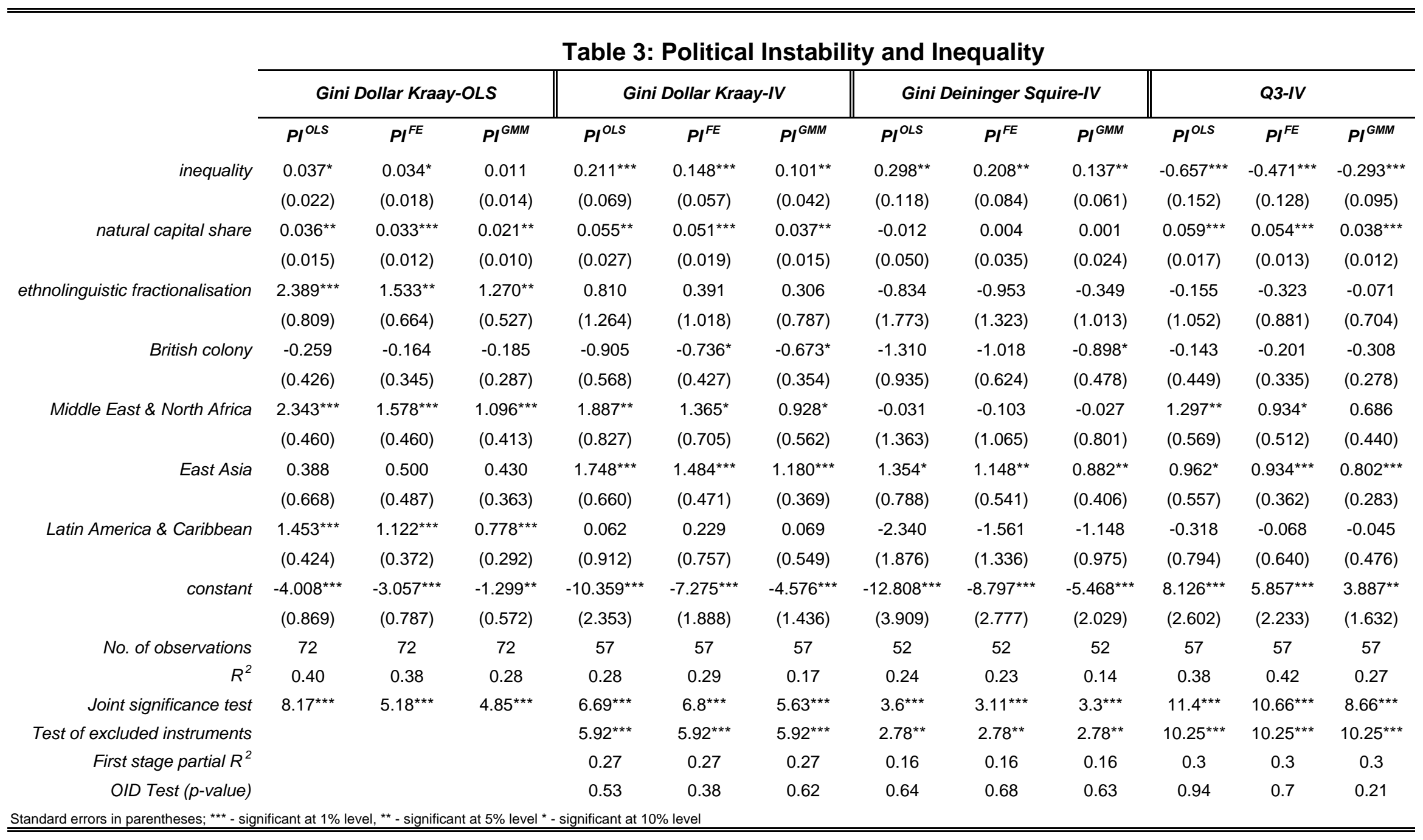




\begin{tabular}{|c|c|c|c|c|c|c|c|}
\hline & $\begin{array}{c}\text { political } \\
\text { transitions } \\
\text { (Polity) }\end{array}$ & $\begin{array}{c}\text { political } \\
\text { transitions } \\
\text { (Gastil) }\end{array}$ & $\begin{array}{c}\text { political } \\
\text { assassinations }\end{array}$ & riots & $\begin{array}{c}\text { riots in } \\
\text { democracies }\end{array}$ & $\begin{array}{c}\text { unsuccessful } \\
\text { coups }\end{array}$ & $\begin{array}{c}\text { coups in } \\
\text { dictatorships }\end{array}$ \\
\hline \multirow[t]{2}{*}{ inequality } & -0.002 & 0.006 & -0.305 & -0.966 & -0.665 & $-0.044^{\star}$ & -0.044 \\
\hline & $(0.021)$ & $(0.016)$ & $(0.189)$ & $(0.88)$ & $(1.264)$ & $(0.027)$ & $(0.038)$ \\
\hline \multirow[t]{2}{*}{ natural capital share } & 0.005 & 0.026 & $-0.271^{\star \star}$ & $-0.994^{\star \star}$ & -0.6 & 0.026 & -0.007 \\
\hline & $(0.016)$ & $(0.017)$ & $(0.11)$ & $(0.483)$ & $(1.185)$ & $(0.019)$ & $(0.027)$ \\
\hline \multirow[t]{2}{*}{ ethnolinguistic fractionalisation } & $1.213^{\star}$ & 0.907 & 5.243 & 34.983 & 69.518 & 0.898 & -0.452 \\
\hline & $(0.658)$ & $(0.728)$ & $(5.672)$ & $(27.202)$ & $(45.089)$ & $(0.751)$ & $(1.027)$ \\
\hline \multirow[t]{2}{*}{ British colony } & -0.219 & -0.147 & -0.123 & 4.139 & -15.899 & 0.106 & -0.156 \\
\hline & $(0.442)$ & $(0.391)$ & $(2.752)$ & $(19.164)$ & (22.09) & $(0.48)$ & $(0.787)$ \\
\hline \multirow[t]{2}{*}{ Middle East \& North Africa } & 0.167 & $1.328^{\star}$ & -3.363 & $-16.354^{*}$ & -15.655 & $2.076^{\star \star}$ & $-1.677^{\star \star}$ \\
\hline & $(0.462)$ & $(0.684)$ & (3.618) & $(9.18)$ & $(11.643)$ & $(0.838)$ & $(0.68)$ \\
\hline \multirow[t]{2}{*}{ East Asia } & 0.627 & -0.119 & $-6.071^{\star}$ & -6.549 & -16.476 & -0.271 & $-1.688^{*}$ \\
\hline & $(0.761)$ & $(0.491)$ & (3.133) & (15.922) & $(20.792)$ & $(0.402)$ & $(0.975)$ \\
\hline \multirow[t]{2}{*}{ Latin America \& Caribbean } & $0.856^{\star \star}$ & 0.048 & 5.075 & -1.359 & -13.506 & $2.148^{\star \star \star}$ & $-1.526^{\star \star}$ \\
\hline & $(0.402)$ & $(0.391)$ & $(5.226)$ & $(10.48)$ & $(12.235)$ & $(0.797)$ & $(0.701)$ \\
\hline \multirow[t]{2}{*}{ constant } & 0.278 & 0.082 & $19.813^{\star \star}$ & $66.792^{\star \star}$ & 49.492 & $1.797^{\star}$ & $4.001^{\star \star}$ \\
\hline & $(0.767)$ & $(0.643)$ & $(8.357)$ & $(31.245)$ & $(44.407)$ & $(0.955)$ & $(1.835)$ \\
\hline No. of observations & 79 & 79 & 77 & 79 & 46 & 77 & 32 \\
\hline$R^{2}$ & 0.1 & 0.13 & 0.13 & 0.1 & 0.13 & 0.21 & 0.25 \\
\hline Joint significance test & 1.34 & 1.4 & 1.25 & 1.56 & 0.67 & $2.06^{*}$ & $2.54^{\star \star}$ \\
\hline
\end{tabular}




\begin{tabular}{|c|c|c|c|c|c|}
\hline & \multicolumn{5}{|c|}{ Table 5: Policy Volatility Measures } \\
\hline & fiscal & trade & & fiscal & trade \\
\hline Germany & 0.02 & 0.02 & Jamaica & 0.09 & 0.16 \\
\hline France & 0.02 & 0.03 & Turkey & 0.09 & 0.10 \\
\hline Netherlands & 0.02 & 0.03 & Ireland & 0.09 & 0.04 \\
\hline Sweden & 0.02 & 0.08 & Benin & 0.09 & 0.12 \\
\hline Austria & 0.03 & 0.03 & Peru & 0.09 & 0.07 \\
\hline United Kingdom & 0.03 & 0.03 & Egypt, Arab Rep. & 0.09 & 0.09 \\
\hline Belgium & 0.03 & 0.03 & Bolivia & 0.09 & 0.08 \\
\hline Switzerland & 0.03 & 0.04 & Syrian Arab Republic & 0.10 & 0.17 \\
\hline United States & 0.03 & 0.02 & Singapore & 0.10 & 0.15 \\
\hline Spain & 0.03 & 0.04 & Pakistan & 0.10 & 0.13 \\
\hline Norway & 0.03 & 0.03 & Israel & 0.10 & 0.06 \\
\hline Italy & 0.03 & 0.03 & Trinidad and Tobago & 0.10 & 0.16 \\
\hline Japan & 0.03 & 0.03 & Lesotho & 0.11 & 0.09 \\
\hline Australia & 0.04 & 0.03 & Haiti & 0.11 & 0.19 \\
\hline Portugal & 0.04 & 0.10 & Chile & 0.11 & 0.05 \\
\hline Canada & 0.04 & 0.03 & Ecuador & 0.11 & 0.16 \\
\hline Denmark & 0.04 & 0.02 & China & 0.11 & 0.10 \\
\hline Iceland & 0.04 & 0.04 & Colombia & 0.11 & 0.06 \\
\hline Finland & 0.04 & 0.05 & Mali & 0.11 & 0.12 \\
\hline New Zealand & 0.05 & 0.04 & Niger & 0.12 & 0.13 \\
\hline Philippines & 0.05 & 0.08 & Ghana & 0.12 & 0.20 \\
\hline Costa Rica & 0.06 & 0.17 & South Africa & 0.12 & 0.09 \\
\hline Panama & 0.06 & 0.08 & Algeria & 0.13 & 0.12 \\
\hline Cote d'Ivoire & 0.06 & 0.08 & Central African Republ & 0.14 & 0.12 \\
\hline Kenya & 0.06 & 0.11 & Gabon & 0.15 & 0.13 \\
\hline Tunisia & 0.06 & 0.09 & Congo, Rep. & 0.16 & 0.16 \\
\hline Greece & 0.06 & 0.15 & Zimbabwe & 0.16 & 0.14 \\
\hline Uruguay & 0.06 & 0.05 & Botswana & 0.16 & 0.10 \\
\hline El Salvador & 0.06 & 0.10 & Rwanda & 0.17 & 0.17 \\
\hline Malaysia & 0.06 & 0.06 & Malawi & 0.17 & 0.22 \\
\hline Mexico & 0.07 & 0.07 & Guinea-Bissau & 0.17 & 0.37 \\
\hline Paraguay & 0.07 & 0.22 & Burundi & 0.17 & 0.37 \\
\hline Mauritius & 0.07 & 0.05 & Togo & 0.18 & 0.25 \\
\hline Madagascar & 0.07 & 0.13 & Senegal & 0.19 & 0.07 \\
\hline Honduras & 0.07 & 0.06 & Nicaragua & 0.20 & 0.17 \\
\hline Hong Kong, China & 0.08 & 0.07 & Mauritania & 0.20 & 0.13 \\
\hline Sri Lanka & 0.08 & 0.07 & Nigeria & 0.21 & 0.12 \\
\hline Papua New Guinea & 0.08 & 0.09 & Burkina Faso & 0.22 & 0.11 \\
\hline Venezuela & 0.08 & 0.12 & Dominican Republic & 0.24 & 0.11 \\
\hline Guatemala & 0.08 & 0.08 & Zambia & 0.24 & 0.23 \\
\hline India & 0.08 & 0.06 & Bangladesh & 0.25 & 0.11 \\
\hline Fiji & 0.08 & 0.10 & Chad & 0.28 & 0.50 \\
\hline Brazil & 0.08 & 0.08 & Argentina & 0.29 & 0.08 \\
\hline South Korea & 0.08 & 0.11 & Cameroon & 0.35 & 0.10 \\
\hline Indonesia & 0.08 & 0.09 & Congo, Dem. Rep. & 0.39 & 0.29 \\
\hline Morocco & 0.09 & 0.09 & Thailand & 0.49 & 0.07 \\
\hline
\end{tabular}




\begin{tabular}{|c|c|c|c|c|c|c|}
\hline & \multicolumn{6}{|c|}{ Table 6: Fiscal Policy Volatility } \\
\hline & \multicolumn{3}{|c|}{ OLS } & \multicolumn{3}{|c|}{ IV } \\
\hline & $P I^{\text {OLS }}$ & $P I^{F E}$ & $P I^{G M M}$ & $\mathrm{PI}^{\text {OLS }}$ & $P I^{F E}$ & $P I^{G M M}$ \\
\hline \multirow[t]{2}{*}{ political instability } & $0.223^{\star \star \star}$ & $0.303^{\star \star \star}$ & $0.312^{\star \star \star}$ & $0.576^{\star \star}$ & $0.849^{\star \star \star}$ & $1.119^{\star *}$ \\
\hline & $(0.056)$ & $(0.067)$ & $(0.079)$ & $(0.225)$ & $(0.308)$ & $(0.527)$ \\
\hline \multirow[t]{2}{*}{ openness } & -0.001 & -0.003 & -0.081 & 0.185 & 0.356 & 0.743 \\
\hline & $(0.239)$ & $(0.235)$ & $(0.207)$ & $(0.668)$ & $(0.735)$ & $(1.015)$ \\
\hline \multirow[t]{2}{*}{ domestic distortions } & $0.664^{*}$ & $0.736^{\star \star}$ & $0.652^{\star}$ & $1.683^{*}$ & $2.052^{\star \star}$ & 2.167 \\
\hline & $(0.352)$ & $(0.325)$ & $(0.330)$ & $(0.934)$ & $(0.949)$ & $(1.361)$ \\
\hline \multirow[t]{2}{*}{ Presidential system } & 0.196 & 0.213 & 0.233 & -0.263 & -0.232 & -0.196 \\
\hline & $(0.231)$ & $(0.236)$ & $(0.257)$ & $(0.369)$ & $(0.362)$ & $(0.426)$ \\
\hline \multirow[t]{2}{*}{ no. of elections } & -0.015 & -0.006 & -0.044 & 0.031 & 0.060 & -0.037 \\
\hline & $(0.049)$ & $(0.048)$ & $(0.045)$ & $(0.072)$ & $(0.076)$ & $(0.069)$ \\
\hline \multirow[t]{2}{*}{ Middle East \& North Africa } & -0.243 & -0.219 & -0.188 & $-0.968^{\star \star \star}$ & $-0.971^{\star \star}$ & -0.873 \\
\hline & $(0.221)$ & $(0.227)$ & $(0.213)$ & $(0.357)$ & $(0.453)$ & $(0.544)$ \\
\hline \multirow[t]{2}{*}{ East Asia } & 0.108 & 0.057 & 0.017 & 0.033 & -0.084 & -0.198 \\
\hline & $(0.214)$ & $(0.205)$ & $(0.215)$ & $(0.301)$ & $(0.284)$ & $(0.299)$ \\
\hline \multirow[t]{2}{*}{ Latin America \& Caribbean } & -0.079 & -0.118 & -0.066 & -0.181 & -0.298 & -0.150 \\
\hline & $(0.163)$ & $(0.173)$ & $(0.182)$ & $(0.208)$ & $(0.230)$ & $(0.296)$ \\
\hline \multirow[t]{2}{*}{ constant } & $-2.587^{\star \star \star}$ & $-2.695^{\star \star \star}$ & $-2.639 * \star \star$ & $-2.508^{\star \star \star}$ & $-2.875^{\star \star \star}$ & $-3.056^{\star \star \star}$ \\
\hline & $(0.329)$ & $(0.309)$ & $(0.302)$ & $(0.559)$ & $(0.608)$ & $(0.689)$ \\
\hline No. of observations & 81 & 81 & 81 & 67 & 67 & 67 \\
\hline$R^{2}$ & 0.41 & 0.44 & 0.39 & 0.34 & 0.36 & 0.24 \\
\hline Joint significance test & $9.2^{\star \star \star}$ & $11.76^{\star \star \star}$ & $7.94^{\star \star \star}$ & $5.21^{\star \star \star}$ & $3.43^{\star \star \star}$ & $2.6^{\star \star}$ \\
\hline OID Test ( $p$-value) & & & & 0.28 & 0.82 & 0.32 \\
\hline
\end{tabular}




\begin{tabular}{|c|c|c|c|c|c|c|c|c|}
\hline & \multicolumn{8}{|c|}{ Table 7: Trade Policy Volatility } \\
\hline & \multicolumn{4}{|c|}{ OLS } & \multicolumn{4}{|c|}{$I V$} \\
\hline & $P I^{\text {OLS }}$ & $P I^{F E}$ & $P I^{G M M}$ & $P I^{\text {OLS }}$ Import duty & $P I^{\text {OLS }}$ & $P I^{F E}$ & $P I^{G M M}$ & $P^{\text {OLS }}$ Import duty \\
\hline \multirow[t]{2}{*}{ political instability } & $0.176^{\star \star \star}$ & $0.233^{\star \star \star}$ & $0.256^{\star \star \star}$ & $0.252^{\star \star \star}$ & $0.334^{\star \star \star}$ & 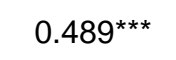 & $0.624^{\star \star \star}$ & $0.666^{\star \star \star}$ \\
\hline & $(0.046)$ & $(0.049)$ & $(0.066)$ & $(0.072)$ & $(0.081)$ & $(0.126)$ & $(0.192)$ & $(0.208)$ \\
\hline \multirow[t]{2}{*}{ accession } & $0.009 * \star \star$ & $0.008^{\star \star}$ & $0.009 * \star \star *$ & $0.011^{*}$ & $0.014^{\star \star \star}$ & $0.011^{\star \star \star}$ & $0.014^{\star \star \star}$ & 0.014 \\
\hline & $(0.003)$ & $(0.003)$ & $(0.003)$ & $(0.006)$ & $(0.004)$ & $(0.004)$ & $(0.005)$ & $(0.010)$ \\
\hline \multirow[t]{2}{*}{ Presidential system } & 0.019 & 0.054 & 0.065 & 0.244 & -0.317 & -0.302 & -0.362 & -0.372 \\
\hline & $(0.221)$ & $(0.216)$ & $(0.235)$ & $(0.317)$ & $(0.278)$ & $(0.294)$ & $(0.361)$ & $(0.491)$ \\
\hline \multirow[t]{2}{*}{ no. of elections } & -0.052 & -0.048 & $-0.074^{\star}$ & -0.087 & -0.030 & -0.017 & $-0.075^{\star}$ & -0.026 \\
\hline & $(0.036)$ & $(0.039)$ & $(0.039)$ & $(0.066)$ & $(0.033)$ & $(0.036)$ & $(0.043)$ & $(0.093)$ \\
\hline \multirow[t]{2}{*}{ Middle East \& North Africa } & 0.085 & 0.132 & 0.135 & -0.105 & -0.076 & -0.051 & -0.037 & -0.925 \\
\hline & $(0.156)$ & $(0.143)$ & $(0.157)$ & $(0.411)$ & $(0.138)$ & $(0.123)$ & $(0.175)$ & $(0.721)$ \\
\hline \multirow[t]{2}{*}{ East Asia } & -0.067 & -0.096 & -0.144 & $-0.484^{*}$ & -0.233 & $-0.298 * \star$ & $-0.421^{\star * \star}$ & -0.673 \\
\hline & $(0.146)$ & $(0.137)$ & $(0.127)$ & $(0.289)$ & $(0.144)$ & $(0.139)$ & $(0.145)$ & $(0.461)$ \\
\hline \multirow[t]{2}{*}{ Latin America \& Caribbean } & -0.025 & -0.046 & -0.011 & -0.153 & -0.097 & -0.145 & -0.104 & -0.239 \\
\hline & $(0.190)$ & $(0.198)$ & $(0.208)$ & $(0.257)$ & $(0.185)$ & $(0.195)$ & $(0.229)$ & $(0.350)$ \\
\hline \multirow[t]{2}{*}{ constant } & $-20.517^{\star \star \star \star}$ & $-18.090 * \star \star$ & $-19.995^{\star \star \star}$ & $-20.192^{\star}$ & $-28.863^{\star \star \star}$ & $-23.466^{\star \star \star}$ & $-29.203^{\star \star \star}$ & -24.806 \\
\hline & $(6.470)$ & $(6.040)$ & $(6.424)$ & $(11.894)$ & $(8.302)$ & $(7.844)$ & $(9.074)$ & $(19.916)$ \\
\hline No. of observations & 81 & 81 & 81 & 73 & 67 & 67 & 67 & 61 \\
\hline$R^{2}$ & 0.45 & 0.47 & 0.44 & 0.47 & 0.46 & 0.46 & 0.37 & 0.39 \\
\hline Joint significance test & $10.26^{\star \star \star}$ & $11.17^{\star * \star}$ & $9.99 * \star \star$ & $7.5^{\star \star \star}$ & $10.32^{\star * \star}$ & $9.57^{\star \star \star *}$ & $7.97^{\star \star \star *}$ & $6.11^{\star \star *}$ \\
\hline OID Test (p-value) & & & & & 0.03 & 0.19 & 0.15 & 0.35 \\
\hline
\end{tabular}


Table 8: Policy Volatility and Political Instability Comparisons

Fiscal Policy Volatility $\quad$ Trade Policy Volatility

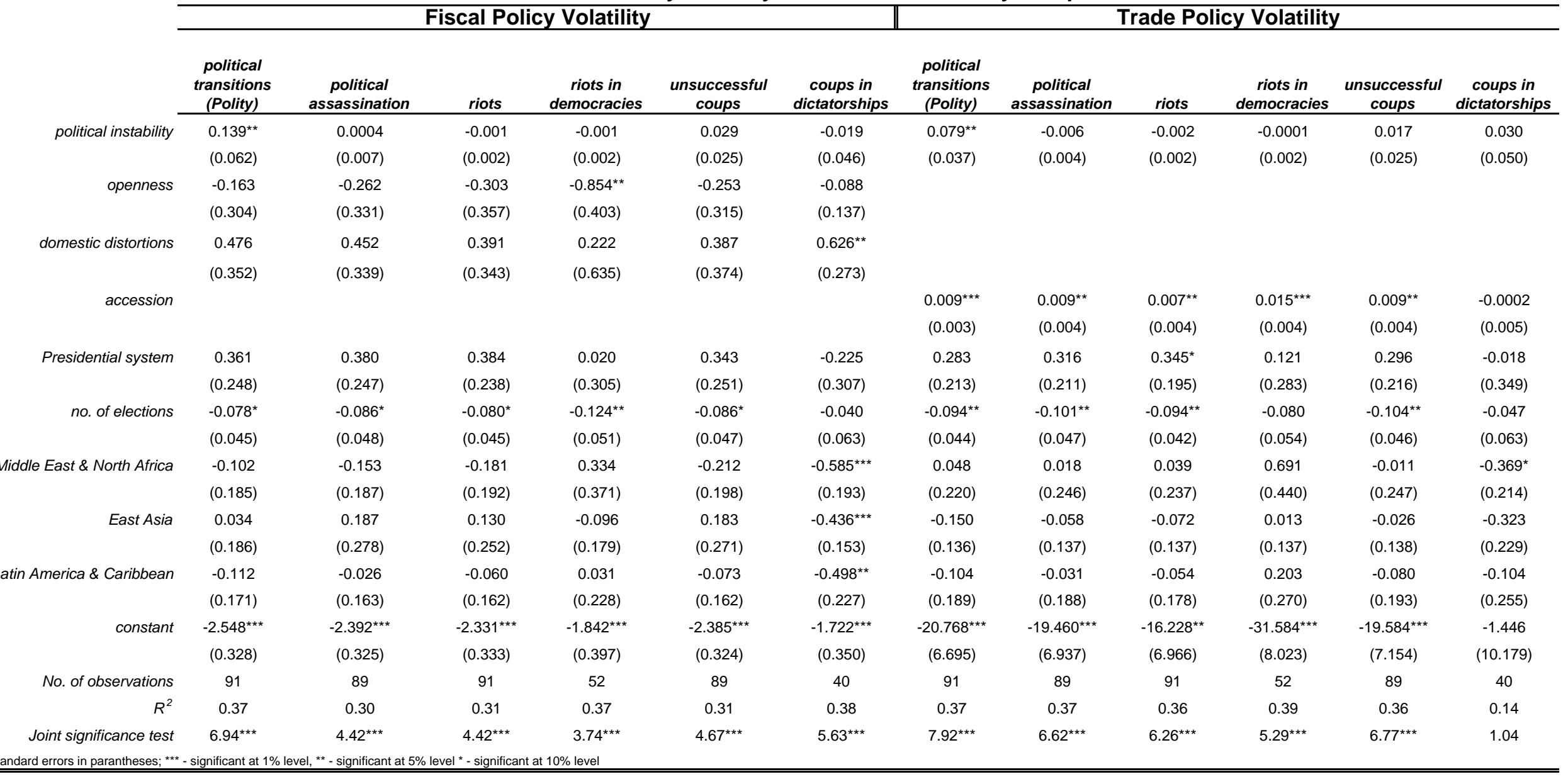


Table 9: Output Volatility and Policy Volatility

\begin{tabular}{|c|c|c|c|c|c|c|c|c|}
\hline & & & & & & & & \\
\hline & OLS & IV & OLS & IV & $\begin{array}{c}\text { Import } \\
\text { duty-OLS }\end{array}$ & $\begin{array}{l}\text { Import } \\
\text { duty-IV }\end{array}$ & OLS & IV \\
\hline \multirow[t]{2}{*}{ fiscal policy volatility } & $0.413^{\star \star \star}$ & $0.974^{\star \star \star}$ & & & & & $0.224^{\star \star \star}$ & 0.086 \\
\hline & $(0.080)$ & $(0.270)$ & & & & & $(0.072)$ & $(0.297)$ \\
\hline \multirow[t]{2}{*}{ trade policy volatility } & & & $0.492^{\star \star \star}$ & $0.740 * \star \star$ & $0.249 * * *$ & $0.542^{\star \star \star}$ & $0.371^{\star \star \star}$ & $0.750 * \star$ \\
\hline & & & $(0.065)$ & $(0.139)$ & $(0.051)$ & $(0.131)$ & $(0.074)$ & $(0.303)$ \\
\hline \multirow[t]{2}{*}{ inflation } & -0.023 & -0.045 & -0.010 & -0.009 & -0.000 & -0.003 & -0.018 & -0.014 \\
\hline & $(0.021)$ & $(0.027)$ & $(0.019)$ & $(0.017)$ & $(0.024)$ & $(0.023)$ & $(0.016)$ & $(0.021)$ \\
\hline \multirow[t]{2}{*}{ terms of trade volatility } & 0.003 & -0.006 & 0.002 & -0.002 & $0.005^{\star}$ & 0.000 & 0.001 & -0.003 \\
\hline & $(0.003)$ & $(0.005)$ & $(0.003)$ & $(0.004)$ & $(0.003)$ & $(0.004)$ & -0.003 & $(0.005)$ \\
\hline \multirow[t]{2}{*}{ exchange rate overvaluation } & $0.002^{*}$ & 0.000 & $0.002^{*}$ & 0.001 & 0.002 & 0.001 & 0.002 & 0.001 \\
\hline & $(0.001)$ & $(0.002)$ & $(0.001)$ & $(0.001)$ & $(0.001)$ & $(0.001)$ & $(0.001)$ & $(0.001)$ \\
\hline \multirow[t]{2}{*}{ government expenditure } & 0.076 & $0.557^{*}$ & 0.125 & 0.270 & -0.187 & 0.099 & 0.208 & 0.358 \\
\hline & $(0.151)$ & $(0.324)$ & $(0.151)$ & $(0.168)$ & $(0.182)$ & $(0.213)$ & $(0.131)$ & $(0.250)$ \\
\hline \multirow[t]{2}{*}{ openness } & 0.130 & $0.175^{\star \star}$ & 0.100 & $0.099 *$ & $0.320^{\star \star}$ & $0.547^{\star \star \star}$ & 0.126 & 0.102 \\
\hline & $(0.130)$ & $(0.084)$ & $(0.094)$ & $(0.055)$ & $(0.132)$ & $(0.130)$ & $(0.081)$ & $(0.067)$ \\
\hline \multirow[t]{2}{*}{ constant } & $1.896^{\star \star *}$ & $2.475^{\star \star \star}$ & $2.003^{\star \star \star}$ & $2.468^{\star \star \star}$ & 1.240 *** & 0.421 & $2.116^{\star \star \star}$ & $2.543^{\star \star *}$ \\
\hline & $(0.390)$ & $(0.503)$ & $(0.343)$ & -0.364 & $(0.457)$ & $(0.570)$ & $(0.304)$ & $(0.385)$ \\
\hline No. of observations & 85 & 77 & 85 & 77 & 76 & 71 & 85 & 77 \\
\hline$R^{2}$ & 0.52 & 0.39 & 0.60 & 0.55 & 0.45 & 0.41 & 0.64 & 0.56 \\
\hline Joint significance test & & $10.54^{\star \star \star}$ & $20.92^{\star \star \star}$ & 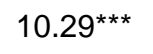 & $16.7^{\star \star \star}$ & $11.68^{\star \star \star}$ & $23.78^{\star \star \star}$ & $7.41^{\star \star \star}$ \\
\hline OID Test ( $p$-value) & & 0.64 & & 0.76 & & 0.9 & & 0.87 \\
\hline 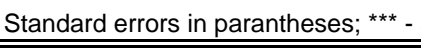 & ificant at & vel, ${ }^{\star \star}-\mathrm{si}$ & nt at 5 & * - signif & at $10 \%$ level & & & \\
\hline
\end{tabular}




\begin{tabular}{|c|c|c|c|c|c|c|}
\hline \multirow[b]{2}{*}{ Political Instability } & \multicolumn{5}{|c|}{ Table 10: Decadal Regressions } & \multirow[b]{2}{*}{$\begin{array}{l}\text { Fixed- } \\
\text { effects }\end{array}$} \\
\hline & $1960 s$ & $1970 s$ & $1980 \mathrm{~s}$ & $1990 s$ & $\begin{array}{l}\text { Random- } \\
\text { Effects }\end{array}$ & \\
\hline \multirow[t]{2}{*}{ inequality } & 0.017 & $0.054^{\star \star \star}$ & $0.045^{\star \star \star}$ & $0.042^{\star \star \star}$ & $0.038^{\star \star \star}$ & 0.023 \\
\hline & $(0.020)$ & $(0.017)$ & $(0.017)$ & $(0.014)$ & $(0.010)$ & (0.019) \\
\hline \multirow[t]{2}{*}{ constant } & -1.158 & $-2.195^{\star \star \star}$ & $-2.368^{\star \star \star}$ & $-1.939^{* \star \star}$ & $-1.863^{\star \star \star}$ & -1.239 \\
\hline & $(0.875)$ & $(0.731)$ & $(0.683)$ & $(0.597)$ & $(0.413)$ & $(0.802)$ \\
\hline No. of observations & 36 & 47 & 58 & 63 & 204 & 204 \\
\hline$R^{2}$ & 0.02 & 0.15 & 0.11 & 0.15 & 0.11 & 0.01 \\
\hline Joint significance test & 0.75 & $9.95^{\star \star \star}$ & $7.47^{\star \star \star}$ & $8.80^{\star \star \star}$ & $15.96^{\star \star \star}$ & 1.41 \\
\hline Fiscal Policy Volatility & $1960 \mathrm{~s}$ & $1970 s$ & $1980 \mathrm{~s}$ & $1990 \mathrm{~s}$ & $\begin{array}{l}\text { Random- } \\
\text { Effects }\end{array}$ & $\begin{array}{l}\text { Fixed- } \\
\text { effects }\end{array}$ \\
\hline \multirow[t]{2}{*}{ political instability } & $0.135^{\star \star}$ & $0.099 *$ & $0.119 * \star$ & $0.325^{\star \star \star}$ & $0.133^{\star \star \star}$ & $0.100^{\star \star \star}$ \\
\hline & $(0.066)$ & $(0.051)$ & $(0.051)$ & $(0.064)$ & $(0.029)$ & $(0.032)$ \\
\hline \multirow[t]{2}{*}{ constant } & $2.414^{\star \star \star}$ & $2.601^{\star \star \star}$ & $2.339 * \star \star$ & $2.298^{\star \star \star}$ & $2.418^{\star \star \star}$ & $2.394^{\star \star \star}$ \\
\hline & $(0.098)$ & $(0.057)$ & $(0.060)$ & $(0.077)$ & $(0.055)$ & $(0.028)$ \\
\hline No. of observations & 64 & 81 & 80 & 81 & 306 & 306 \\
\hline$R^{2}$ & 0.06 & 0.04 & 0.06 & 0.23 & 0.11 & 0.04 \\
\hline Joint significance test & $4.23^{\star \star}$ & $3.85^{\star}$ & $5.49 * *$ & $26.12^{\star \star \star}$ & $21.71^{\star \star \star}$ & $9.93^{\star \star \star}$ \\
\hline Trade Policy Volatility & $1960 s$ & $1970 s$ & $1980 \mathrm{~s}$ & $1990 s$ & $\begin{array}{l}\text { Random- } \\
\text { Effects }\end{array}$ & $\begin{array}{l}\text { Fixed- } \\
\text { effects }\end{array}$ \\
\hline \multirow[t]{2}{*}{ political instability } & $0.178^{\star \star}$ & 0.057 & $0.162^{\star \star \star}$ & $0.305^{\star \star \star}$ & $0.136^{\star \star \star}$ & $0.089^{\star \star}$ \\
\hline & $(0.082)$ & $(0.057)$ & $(0.057)$ & $(0.058)$ & $(0.033)$ & $(0.036)$ \\
\hline \multirow[t]{2}{*}{ constant } & $1.831^{\star \star \star}$ & $2.490 * \star \star$ & $2.387^{\star \star \star}$ & 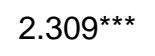 & $2.272^{\star \star \star}$ & $2.244^{\star \star \star}$ \\
\hline & $(0.096)$ & $(0.064)$ & $(0.062)$ & $(0.073)$ & $(0.060)$ & $(0.032)$ \\
\hline No. of observations & 65 & 81 & 81 & 81 & 308 & 308 \\
\hline$R^{2}$ & 0.07 & 0.01 & 0.09 & 0.23 & 0.1 & 0.03 \\
\hline Joint significance test & $4.74^{\star \star}$ & 1.00 & $8.04^{\star \star \star}$ & $27.30^{\star \star \star}$ & $17.56^{\star \star \star}$ & $5.93^{\star \star}$ \\
\hline
\end{tabular}

In the first stage regressions, we regress Polity on per capita GDP, schooling, gender inequality in schooling, an oil dummy and by decade. We use Arellano-Bond GMM system estimator to run the first stage regressions by decade and calculate political instability as the standard error of the residuals.

Policy volatility is calculated in the same way by decade.We use the Anderson-Hsiao estimator. 